\title{
Faith and resilience
}

\section{Daniel Howard-Snyder ${ }^{1}$ (D) . Daniel J. McKaughan ${ }^{2}$}

Received: 26 May 2021 / Accepted: 2 November 2021 / Published online: 8 January 2022

(c) The Author(s), under exclusive licence to The Associates for Philosophy of Religion 2021

\begin{abstract}
In this short essay, we sketch a theory of faith that features resilience in the face of challenges to relying on those in whom you have faith. We argue that it handles a variety of both religious and secular faith-data, e.g., the value of faith in relationships of mutual faith and faithfulness, how the Christian and Hebrew scriptures portray pístis and 'émûnāh, and the character of faith as it is often expressed in popular secular venues.
\end{abstract}

Keywords Faith $\cdot$ Faithfulness $\cdot$ Resilience $\cdot$ Reliance $\cdot$ Reliability $\cdot$ pístis · 'ěmûnāh

\section{Introduction}

When you put your faith in someone for something, you rely on them for it, or you are at least disposed to do so. This much seems obvious. We will take it for granted here. When you put your faith in someone for something, you are also at least somewhat resilient in the face of challenges to relying on them for it. This is not as obvious. Nevertheless, we aim to make a case for it here.

We develop our case in six stages. First, we state a theory of relational faith, define its key terms, and adumbrate our methodology. Second, we argue that, because our theory posits faith's resilience, it can handle several items of data regarding both faith and faithfulness, most notably faith's role and value in relationships of mutual faith and faithfulness. Third, we substantiate our claim that relational faith bears a necessary relation to resilience. Fourth, we argue that our theory handles positive correlations between faith and resilience in secular contexts, specifically in expressions of pístis and fides in the ancient Greco-Roman world and expressions of faith

Daniel Howard-Snyder

Daniel.Howard-Snyder@wwu.edu

Daniel J. McKaughan

daniel.mckaughan@bc.edu

1 Department of Philosophy, Western Washington University, Bellingham, WA 98225, USA

2 Department of Philosophy, Boston College, 351N Stokes Hall, Chestnut Hill, MA 02467-3806, USA 
in a wide variety of contemporary secular venues. Fifth, we argue that our theory handles positive correlations between faith and resilience in religious contexts, specifically in expressions of pístis in the New Testament and 'ěmûnāh in the Hebrew scriptures, and in the role of faith in the biblical themes of covenant and salvation, the lives of exemplars of faith in God, and the lives of ordinary people of faith today. Finally, we zoom-in on resilience itself. What, exactly, is the nature of the resilience involved in faith? The psychological literature informs our answer.

In doing all this, we aim to understand the faith God desires of people, according to the Abrahamic tradition, and the faith that permeates a variety of human relationships, viewing them as similar phenomena. We focus on relational faith, specifically the claim that it involves resilience. We do not discuss its status as a virtue or vice, or other manifestations of faith, e.g., propositional faith.

\section{A theory of relational faith}

Put abstractly, our proposal is this:

Resilient Reliance For you to have faith in someone for something is for you to be disposed to rely on them to come through with respect to it, with resilience in the face of challenges to doing so, because of your positive stance toward their coming through.

So, for example, for Samuel to have faith in God as providential governor of the universe is for him to be disposed to rely on God to come through in that capacity, with resilience in the face of challenges to doing so, because of his positive stance toward God's governance.

Several comments are in order. We begin with the notion of a positive stance, explaining why we include it in the theory.

Like fear, hope, anger and other complex psychological states, faith has builtin to it what's needed to explain behavior. By way of illustration, all you need to know to understand why Christina behaves in certain ways-confessing her sins, praying regularly, studying the Bible, gathering with Christians, helping the disadvantaged, relying on the two Great Commandments to make moral, social, and political decisions, taking the sacraments, observing the holy days, and so on-is that she has faith in Jesus as her Lord. Naturally, we might wonder why she has faith but, once we've learned that she does, we can understand why she performs actions that constitute relying on Jesus as her Lord.

But Christina's faith can explain her behavior only if it involves both conative and cognitive states. However, not any old states will do. We cannot explain her relying-on-Jesus behavior by saying that she wants to follow Jesus as Lord and she believes that he will not come through on that score, or by saying that she believes that Jesus will come through as Lord and she wants him not to do so. Disbelief and disdesire are too "negative" to explain her behavior; more "positive" cognitive and conative states are required. 
At a first approximation, for Christina to be in a positive cognitive state toward Jesus coming through as her Lord is for her to be in some cognitive state or other that represents him as coming through, with three features: (1) it has the propositional content that Jesus will come through, (2) it disposes her to take a stand on behalf of the truth of that proposition, and (3) it is responsive to her evidence for its truth and/or it is the output of a cognitive faculty the exercise of which is aimed at forming true positive cognitive states. Belief that Jesus will come through has these features but - crucially - there are other candidates, e.g., a high-enough credence or confidence that he will come through or, depending on the details, accepting, trusting, hoping, or belieflessly assuming that he will; and propositional reliance and imaginative assent might also be candidates. ${ }^{1}$ Two qualifications. First, just as you can put your hope in a forgetful friend to fetch you at the airport even though you only believe the "thinner" proposition that it's more likely than not that they will do so, so Christina can have faith in Jesus as her Lord even though she only believes a "thinner" proposition. Second, for all we know, it's possible for a creature capable of faith to have non-propositional representations of the relied-upon coming through, e.g., imagistic representations. ${ }^{2}$ We include these two options under the rubric of a positive cognitive state. Upshot: a wide variety of states can be a positive cognitive state.

Note well: the positivity involved in a positive cognitive state is a disposition to take a stand on behalf of its truth in contrast with taking a stand against its truth, or no stand at all. Nothing else. You can be in a positive cognitive state toward a proposition without regarding its truth as good or desirable. Suppose you believe that you will be unjustly executed tomorrow. Then you are in a positive cognitive state toward that proposition, and so you are disposed to take a stand on behalf of its truth. Even so, you regard its truth as bad or undesirable.

For Christina to be in a positive conative state toward Jesus coming through as her Lord is for her to be in some conative state or other that motivates her to rely on Jesus to come through in that capacity. Wanting him to come through counts butcrucially - there are other candidates. By way of illustration, and switching examples, imagine a meth-addict who does not want to stop taking meth but who, upon coming to recognize how much better his life might be if he were to stop, wants to want to stop taking meth. He has a second-order desire to change his first-order desire. Nevertheless, he might have faith in himself to stop. For, although he has no first-order desire to stop, it still matters to him that he stops since he wants to want to stop. In addition to first- and second-order desires, other options for a positive conative state, in Christina's case, include looking with favor on Jesus coming through, being for it, a felt attraction to it, caring about it, it mattering to her, being emotionally invested in it, affection for him in that capacity, and a commitment to him as Lord, among other possibilities, all of which have been mentioned in the literature. ${ }^{3}$

\footnotetext{
1 See Alston (1996); Audi (2011); Howard-Snyder (2019), McKaughan (2013; 2016); Pojman (1986); Rath (2017); Schellenberg (2005).

2 Cf. Beck (2013).

3 Cf. Alston (1996), Adams (1999), Audi (2011), Buchak (2017), Howard-Snyder (2013), Jackson (2021), Kvanvig (2018), McKaughan (2016; 2017).
} 
We include these under the rubric of a positive conative state. Upshot: a wide variety of states can be a positive conative state. We also allow that some conative states can be brought about by an act of volition, e.g., Christina might choose to make a commitment to Jesus as Lord.

Notice that, on Resilient Reliance, relational faith is a role-functional psychological state, not a mere combination of four items. For a psychological state to be an instance of faith in someone for something is for it to take as input any of a wide variety of combinations of positive conative and positive cognitive states toward them coming through with respect to it and to give as output a disposition to rely on them to come through with resilience in the face of challenges.

So then, Christina's faith in Jesus as her Lord can explain her relying-on-Jesus behavior, and that's because her faith involves both positive conative and positive cognitive states toward doing so. For convenience, we collect both under the label of a positive stance, which appears in our theory.

Just a word on "a disposition to rely". "Rely" can be used as an active and stative verb. We use it as an active verb denoting a certain sort of non-basic action, one you perform by doing other things, e.g., relying on a personal trainer by following their advice and attending their sessions. ${ }^{4}$ On our view, you can have faith in someone for something even while you are not performing the act of relying on them for it - as when you are fast asleep or absorbed in something else-provided you have a disposition to perform the act of relying on them for it.

Later, we'll say more about the resilience involved in faith. For now, note that it need not dispose us to overcome all possible challenges. We can be more or less resilient depending on the range of challenges to which we would respond by overcoming them. This is one way in which we can have more or less faith.

We are now in a position to assess Resilient Reliance, specifically its claim that faith involves a disposition to rely, with resilience in the face of challenges to doing so. But first, a word on methodology. ${ }^{5}$

A theory of faith will strive to somehow handle the data of faith. A faith-datum is, in general, any consideration about faith that does not belong to a well-formed theory of faith and which pistologists - those who study faith and related phenomena-collectively have good reason to affirm. At a first approximation, a theory of faith handles a faith-datum just when it accommodates and explains it. It accommodates a faith-datum just when the datum is likely to hold or be true given the theory, and it explains it just when it posits something such that, if it holds or is true, then the datum holds or is true because the posited thing holds or is true. (We leave open the varieties of good reason, likelihood, and because-relations.)

Here's a wrinkle. Suppose a theory of faith posits something such that, if it holds or is true, we are unable to tell whether the datum holds or is true because the posited thing holds or is true. That might be due to the fact that, to justify the becauseclaim, advances in empirical psychology must first occur. Even so, a datum might be pre-theoretically plausible, and a theory might explain its plausibility. Let's say that

\footnotetext{
${ }^{4}$ We explore the nature of the act of relying in Howard-Snyder and McKaughan (unpublished).

5 We follow Bengson et al. (2022), with simplification. See their book for details and defense.
} 
a theory explains the plausibility of a faith-datum just when it posits something such that, if it holds or is true, then it is plausible that the datum holds or is true because of the posited thing holding or being true. So, we must modify what we said earlier: a theory of faith handles a faith-datum just when it accommodates and explains it or, if we are unable to tell whether it explains the datum, it explains its plausibility. ${ }^{6}$

Accommodation, explanation, and rendering-plausible focus on how well a theory of faith handles the faith-data. In principle, the claims that constitute a theory might do well on that score even though there is no positive reason to think those claims are true or they face serious objections. A theory of faith, therefore, must substantiate its claims. A theory of faith substantiates its claims just when it gives both good reasons for them and adequate replies to objections. While there are other criteria of assessment-e.g., integrating the claims of a theory with our best picture of the world, or evaluating simplicity, naturalness, fruitfulness, elegance, and beauty-we will focus on accommodation, explanation, rendering-plausible, and substantiation.

We now turn to our first source of data: faithfulness and its relation to faith.

\section{Faith and faithfulness}

A theory of faith will aim to handle the data of faithfulness: what it is, how it relates to faith, and their role and value in relationships of mutual faith and faithfulness.

\section{The nature of faithfulness and its relationship to faith}

We begin with an observation: for you to be faithful to someone is not for you to be full of faith or especially "faithish". Rather, as William Alston says, "[a] faithful person is one who is worthy of faith being reposed in [them], trustworthy, reliable, loyal, steadfast, constant, and so on". ${ }^{7}$ This is exactly right. Call it Alston's Axiom.

We can use Alston's Axiom to reveal the nature of faithfulness given a theory of faith. On our theory, faith, in slogan form, is resilient reliance, by which we mean a disposition to rely with resilience in the face of challenges. Now: if faith is resilient reliance, then, on Alston's Axiom, a person is worthy of faith being reposed in them for something only if and because they are disposed to come through reliably with respect to it, with resilience in the face of challenges to doing so. Further, just as our faith in someone for something can explain our behavior because faith involves a positive stance toward them coming through, so our faithfulness to someone for something can explain our behavior because faithfulness involves a positive stance toward our coming through for them. It follows that:

\footnotetext{
${ }^{6}$ We thank Dennis Whitcomb for this modification. Cf. Whitcomb et al. (2017). Notice that we can show that a theory accommodates, and explains or renders-plausible, a faith-datum even though we do not show that it does so better than competing theories, a task we leave for elsewhere.

7 Alston (1996), 13, emphasis added. Cf. Audi (2011) and McKaughan and Howard-Snyder (2021).
} 
Resilient Reliability For you to be faithful to someone for something is for you to be disposed to come through reliably with respect to it, with resilience in the face of challenges to doing so, because of your positive stance toward your coming through.

In slogan form, faithfulness is resilient reliability, by which we mean a disposition to come through reliably with resilience in the face of challenges. So, for example, for David to be faithful to God, in keeping the Torah, is for him to be disposed to keep it reliably, with resilience in the face of challenges to doing so, because of his positive stance toward keeping it. Notice that, like faith, faithfulness is a role-functional psychological state. It takes as input any of a wide variety of combinations of positive stances and gives as output a disposition to come through reliably, with resilience in the face of difficulties in doing so.

Taken together, our theory of faith and faithfulness can handle three items of faith-related data. The first is this:

Relying-and-Coming-Through Just as faith in someone for something is somehow related to relying on them for it, so faithfulness to someone is somehow related to coming through for them for it.

After all, when you put your faith in someone for something, what could be going on if you are not in some way or another relying on them for it? It is implausible in the extreme to suppose that faith is not in any way at all related to relying. Mutatis mutandis, the same goes for faithfulness. Our theory accommodates and explains Relying-and-Coming-Through. For, if faith involves a disposition to rely, then not only is it likely that faith is somehow related to relying, it is also because it involves that disposition that it is so related; and, if faithfulness involves a disposition to come through reliably, then not only is it likely that faithfulness is somehow related to coming through, it is also because it involves that disposition that it is so related.

Our second faith-datum arises from the observation that people identifiable as "faithish," i.e., those characterized by a tendency to have faith in others, and people identifiable as faithful, i.e., those characterized by a tendency to be faithful to others, tend not to be fickle or flighty in their relationships. While this phenomenon can be observed in many secular relationships, it can also be observed in people of religious faith, i.e., those who structure and unify their lives around their devotion to God or some other religious ultimate reality. We can put it like this:

Neither-Fickle-Nor-Flighty Faithish people and faithful people tend not to be fickle or flighty in their relationships.

Our theory accommodates this datum. For, if faith is resilient reliance, it is likely that faithish people will tend not to be disposed to rely on others in a sporadic fashion and tend not to be disposed to stop relying on them. Mutatis mutandis, the same goes for faithfulness. However, we cannot justify from our armchairs the claim that the faithish and the faithful tend not to be fickle and flighty because of the dispositions our theory posits. Perhaps these correlations hold for some other reason. To settle the matter, empirical psychologists must create valid measures, and design and conduct relevant, reliable, and replicable studies-which 
they have yet to do. ${ }^{8}$ Still, Neither-Fickle-Nor-Flighty is pre-theoretically plausible, and our theory can explain its plausibility. For, if faith and faithfulness both involve resilience in the face of challenges, it is plausible that they are negatively correlated with fickleness and flightiness because of their resilience.

Our third datum is this:

Reciprocity Faith and faithfulness are reciprocals,

at least when all goes well-a qualification we will leave implicit in what follows. The reciprocity of faith and faithfulness consists in their complementing each other, answering each other, so to speak. Our theory accommodates and explains Reciprocity. For, first of all, on our theory, when you have faith in someone for something, you have a positive stance toward them coming through with respect it, which their faithfulness answers with a positive stance toward the same, and it is (partly) because of your shared positive stances that your mutual faith and faithfulness answers each other. Second, on our theory, when you have faith in someone for something, you are disposed to rely on them to come through with respect to it, which their faithfulness answers by them being disposed to come through reliably, and it is (partly) because of these dispositions that your mutual faith and faithfulness answer each other. Third, on our theory, when you have faith in someone for something, you'll be resilient in the face of challenges to relying on them to come through with respect to it, which their faithfulness answers by their being resilient in the face of challenges to coming through reliably, and it is (partly) because of your mutual resilience that your mutual faith and faithfulness answer each other. So it is that our theory accommodates and explains Reciprocity.

We now turn to the role and value of faith in relationships of mutual faith and faithfulness.

\section{The role and value of faith in relationships of mutual faith and faithfulness}

We human beings are deeply familiar with relational faith. That's because it is the rare one among us who can survive-much less flourish-without placing faith in others. Oftentimes, when we place our faith in someone, e.g., when we place our faith in someone as a spouse, we bind ourselves to them in a particular way, and, when all goes well, our faith in them is met by their faithfulness to us as a spouse, and their faith in us as a spouse is met by our faithfulness to them in that capacity, all of which enhances the bond between us. We find such relationships of mutual faith and faithfulness not only between spouses, but also between lovers and between friends; between parents and their children; between siblings and between other relatives, e.g., spouses and their in-laws; between caretakers and dependents, teachers and students, employers and employees; between associates, teammates, and soldiers; and between people and their gods or God. We also find such relationships

\footnotetext{
${ }^{8}$ For an evaluative review of psychological research related to trust in God and proposals for future research on trust and faith in God more attuned to investigating their potential relations to reliance, resilience, and associated cognitive and conative states, see Hook et al. (2021).
} 
between groups, e.g., citizens and political representatives, businesses and customers, and one state and another, e.g., in interstate commerce and in the making and keeping of pacts and treaties. ${ }^{9}$

Relationships of mutual faith and faithfulness are constituted by the role that faith and faithfulness play in them. What role does faith play in such a relationship? We submit that, at a first approximation, faith's role is to help bind together its partners by enabling them to rely on each other. When all goes well, the result is that they both experience the goods that can arise from within the relationship by relying on each other. For example, when people marry, they place their faith in each other as spouses, and thereby rely on each other for emotional intimacy and support, companionship, care for personal well-being, sexual fulfillment, and shared domesticity, among other things, depending on cultural, personal, and other expectations. And, when all goes well, they are faithful to each other as spouses, and thereby come through for each other with respect to these goods.

But not always does all go well. Spouses can at times be aloof, distracted, uncaring, uninterested, and lazy, among other things, thereby diminishing these goods, sometimes even putting them in peril. Even then-indeed, especially then-faith's role is to help bind together spouses by enabling them to continue relying on each other, despite difficulties, in the hope that things will change for the better. Of course, our spouses are not the only ones who can put our faith in them to the test. Our own devils and demons can have a hand in it too. For any number of reasons-fatigue, anger, revenge, disappointment, petulance, bitterness, or an impoverished ability to forgive, to name a few-we might withdraw from relying on them, and instead rely on someone or something else for the goods of marriage, or forego them altogether. No doubt, other things can have a similar effect, e.g., serious disagreement and deep change.

The value of faith in a marriage, therefore, consists in its enabling its partners to continue relying on each other through difficulty, so that they might experience those goods together, in the short-term and the long-run, through fair weather and stormy seas. (Of course, we don't mean to deny that other things, e.g., faithfulness and love, contribute to their experience of those goods. Our focus is faith.) But there's more to the value of faith in marriage. For, just as there can be impressive works of art and nature, so there can be impressive works of humanity, among which we sometimes find marriage. We often marvel at a long marriage, one good on the whole even if not in every temporal part. The goodness of a good, long marriage consists not only in the goods that can arise from it but also in the goods its partners display, e.g., integrity and solidarity, and the goods the relationship itself displays,

\footnotetext{
${ }^{9}$ Objection Our theory applies to individual people, not groups of people. Reply Correct. Fortunately, on a common view of collective responsibility, collectives can have a psychology beyond that of their members, and so, on that view, our theory can be easily extended to groups of people. However, if there are no collectives, then no group of people can enter into relationships of mutual faith and faithfulness. Still, sentences like "Vermont has more faith in the CDC than Mississippi does" or "Israel is more faithful to God than it was" can express truths since, arguably, their truth-makers can be understood wholly in terms of the psychology of individual citizens. For details, see Smiley (2017).
} 
e.g., stability, each of which is partly due to the faith they place in each other, faith retained through the assaults of chance, choice, and change, about which more in a moment.

Although the specifics of the role and value of faith in a relationship of mutual faith and faithfulness will vary according to the kind of relationship it is, e.g., friendship, marriage, collegiality, etc., we can generalize from these observations about marriage, as follows:

Role The role of faith in a relationship of mutual faith and faithfulness is to help bind its members together by somehow enabling them to continue relying on each other despite difficulty.

Value The value of faith in a relationship of mutual faith and faithfulness consists in goods that can arise from or be exhibited by the way in which faith helps to bind its members together.

Our theory accommodates Role and explains its plausibility since, if faith is resilient reliance, then we will be disposed to rely on those in whom we place our faith, with resilience in the face of challenges to doing so, in which case not only is it likely that the binding-role of faith in such relationships will be well-served, it is also plausible that, because of that constitutive disposition, faith's binding-role will be well-served. Our theory accommodates Value since, if faith is resilient reliance, then, given its constitutive disposition, it is likely that the value of faith in those relationships will consist in goods that can arise from or be exhibited by the way in which that disposition helps to bind its members together.

That leaves explaining the plausibility of Value. Let's focus first on the aspect of the value of faith that involves goods that can arise from relationships of mutual faith and faithfulness. Our theory explains the plausibility of this aspect since, if faith is resilient reliance, then given its constitutive disposition, it is plausible that (partly) because of the way in which that disposition helps to bind its members together, those goods that we rely on others for can arise within such relationships. Now let's focus on the aspect of the value of faith in relationships of mutual faith and faithfulness that involves goods that can be exhibited both by its members, e.g., integrity and solidarity, and by features of the relationship itself, e.g., stability. We will illustrate with a good, long marriage. If faith is resilient reliance, then, given its constitutive disposition, it is plausible that partners to a good, long marriage can exhibit the goods of integrity and solidarity because of the way in which that disposition helps to bind them together, and the same goes for the stability of the relationship. Consider, first, the good of integrity. ${ }^{10}$ By repeatedly exercising resilient reliance, partners to a good, long marriage glue together their earlier selves, who committed to relying on the other-for better, for worse, for richer, for poorer, in sickness and in health, till death do us part-and their later selves, who kept that commitment, an integrity all the more admirable for each partner having continued to rely on the other even when the other's coming through was more like the tide's ebbing than its flowing, and even when they felt the strong pull of withdrawing wash away

${ }^{10}$ Cf. Cox et al. (2021). 
the ground from under their feet. Likewise for the good of solidarity. By repeatedly exercising resilient reliance, they threw in their lot with each other, again and again, thereby creating, fashioning, and sustaining their own we're-in-this-together-ness, a solidarity all the more unyielding for their having overcome not only the seismic events of shared life but also the cumulative effect of its daily drip-drip-drip. ${ }^{11}$ And the same goes for the good of stability. By repeatedly exercising resilient reliance, they contributed to their marriage being something that would not only endure the test of time, but something that possessed the sustenance out of which could grow both the support each needed to explore their potential and interests, and the security to pursue long-term joint ventures, e.g., a family, a farm, a business, or a fearsome doubles-team, among many other possibilities.

What we've said here about marriage in showing how our theory renders-plausible the second aspect of Value can be said, mutatis mutandis, about other kinds of relationships of mutual faith and faithfulness. ${ }^{12}$

Here's another observation. While we recognize that unfaithfulness can harm a relationship, we rarely recognize that faithlessness can do the same. But it can. Indeed, a surefire way to destroy a marriage is to rely on others, and not on your spouse, for the goods of emotional intimacy and support, etc., just as failing to come through for them for those selfsame goods can. And the same goes, mutatis mutandis, for other relationships of mutual faith and faithfulness. That is,

Faithlessness Faithlessness can destroy relationships of mutual faith and faithfulness just as unfaithfulness can.

Our theory accommodates and explains Faithlessness. For, if faith is resilient reliance, then not only is it likely that a marriage, friendship, etc. can be destroyed when its partners fail to be disposed to rely on each other for the goods that can arise from it, it is also because partners fail to be so disposed that faithlessness can destroy that relationship.

We now turn to substantiate our claim that faith is not only contingently, but necessarily, related to resilience.

\footnotetext{
${ }^{11}$ Cf. Preston-Roedder (2018).

12 Objection Even if faith is resilient reliance, and even if we have faith in our spouses, it is more plausible that we are disposed to continue behaving in ways that constitute our relying on them for the goods of marriage, despite difficulties, because of our love for them and not because of our faith in them. Reply. Suppose Eleonore Stump (2006) is right: our love of our spouses consists in, most fundamentally, two desires: a desire for their well-being and a desire for a specific sort of union, marital union. Label them the marital desires. Then, on Stump's view, marital love just is the marital desires. Now, in the context of a marriage, either the marital desires entail a disposition to continue behaving in ways that constitute our relying on our spouses for the goods of marriage, despite difficulties, or they do not. If they do not, then marital love cannot explain the plausibility of the disposition in question as well as faith in them can, given that faith is resilient reliance. If, however, the marital desires do entail a disposition to continue behaving in ways that constitute our relying on them for the goods of marriage, despite difficulties-say, because the desire for marital union entails that disposition-then marital love will explain the plausibility of the disposition in question, but it will not do so better than faith in them does. Rather, they will do so because and only because faith in them does, given that faith is resilient reliance. So, on Stump's view of marital love, the objection is false. Mutatis mutandis, the same goes for other views of love.
} 


\section{Reason to think faith essentially involves resilience}

We offer three considerations which together suggest that faith essentially involves resilience.

First, a consideration that we will not develop here: our theory-a theory that includes the claim that faith essentially involves resilience-better accommodates, and explains or renders-plausible, the faith-data than competing available theories. Absent the posit of faith's essential resilience, our theory does not fare as well on that score.

Second, consider faith-resilience conjunction-tests, cases in which an attribution of faith is paired with an attribution of no disposition at all to rely with resilience in the face of challenges. Assertions of the form "I have faith in them, but I'm inclined to stop relying on them at the first sign of their not coming through" are puzzling, whether uttered by a fair-weather spouse or a spineless theist. To our ear, at any rate, what these folks say is jarring. What do you mean you have faith in them as a spouse, but you're going to stop relying on them at the first sign of their not coming through? What do you mean you have faith in God, as providential governor of the world, while you live a comfortable life, but you'd stop relying altogether on God in that capacity if things got even a wee bit difficult for you? Assertions of faith sound at loggerheads with denials of any tendency whatsoever to be resilient in the face of challenges to continue to rely, which provides us with defeasible reason to think that faith essentially involves resilience.

The third consideration begins with our earlier observation that relationships of mutual faith and faithfulness are constituted by the role each plays in them. As we indicated there, the role of faith in such a relationship is to help bind its members together by somehow enabling them to continue relying on each other despite difficulties. Similarly, the role of faithfulness is to help bind its members together by somehow enabling them to continue coming through for each other despite difficulties. Here we focus on the role of faith. Based on our observation, we can put the third consideration simply: if faith is only contingently related to resilience, then there could be a relationship of mutual faith and faithfulness in which nothing plays the faith-role, in which case it really wouldn't be a relationship of mutual faith and faithfulness. We can unpack this simple thought into a formal argument.

Suppose, for reductio, that faith is only contingently related to its capacity to somehow enable people to continue relying despite difficulty. If faith is only contingently related to this capacity, then there could be an instance, $r$, of a relationship of mutual faith and faithfulness such that, in $r$, faith exists; in $r$, faith lacks the capacity to somehow enable its members to continue relying despite difficulty; and, in $r$, nothing plays the faith-role. Thus, by logic, $r$ is a relationship of mutual faith and faithfulness and, in $r$, nothing plays the faith-role. But, necessarily, for any $x$, if $x$ is a relationship of mutual faith and faithfulness, then, in $x$, something plays the faithrole. (Why necessarily? Because a relationship of mutual faith and faithfulness is constituted, in part, by there being something that plays the faith-role.) So, by logic, in $r$, something plays the faith-role, and, in $r$, nothing plays the faith-role. Reductio complete. So, faith is not only contingently related to its capacity to somehow 
enable people to continue relying despite difficulty-which is to say, faith essentially involves resilience. ${ }^{13}$

So it is that faith essentially involves resilience. We now return to the data of faith. We have argued that our theory accommodates, and explains or renders-plausible, Relying-and-Coming-Through, Neither-Fickle-nor-Flighty, Reciprocity, Role, Value, and Faithlessness. In doing so, we have, in effect, given a recipe for drawing this conclusion. It would be tiresome to mix the batter for each of the remaining items of faith-data. We leave it to the reader to follow the recipe.

\section{Faith and resilience in secular contexts}

We begin with faith and resilience in secular contexts, specifically pistis and fides in the ancient Greco-Roman world and faith in a wide variety of contemporary secular venues.

\section{Pistis and fides in the ancient Greco-Roman world}

Historian Teresa Morgan has done us a great service in her study of the practice of pistis and fides in Greek- and Latin-speaking peoples of the two centuries surrounding the birth of Jesus. Here we summarize some of her main findings, what we will call.

Pístis and Fides in the Greco-Roman World In the ancient Greco-Roman world, pistis and fides, on the one hand, and resilience, on the other hand, are widely positively-correlated.

According to Morgan, by the time of the period of her study, the complex terms pistis and fides shared central meanings, e.g., faith, trust, faithfulness, trustworthiness, and "good faith" ${ }^{14}$ She argues that (1) pístis and fides were portrayed as crucial to sustaining relationships of mutual faith and faithfulness that permeated the Greco-Roman world "at every socio-economic level, between individuals and

\footnotetext{
13 One might wonder how, on our theory, relational faith is distinct from relational trust. The long answer is in McKaughan and Howard-Snyder (unpublished a). Here's the short answer. (1) The experts on trust offer many theories. Some say a disposition to rely is unnecessary, in which case trust is not even close to faith. Others say that a disposition to rely is necessary for trust but not sufficient, while yet others that it is necessary and sufficient. But none says trust essentially involves resilience in the face of challenges to relying. So, the experts on trust implicitly distinguish trust from faith. (2) Of course, the experts could all be wrong. Is there some reason to suppose they're right, i.e., to suppose trust does not essentially involve resilience in the face of challenges to relying? We think so. That's because it seems we can trust someone for something even when we are not the least bit resilient in the face of challenges to relying on them. We trust our pharmacist to provide our medication but, if they don't have it, we aren't the least bit disposed to continue relying on them to provide it, we just go to at another pharmacist; we trust the oncoming driver to stay on their side of the road but, if they don't, we aren't the least bit disposed to continue relying on them to do so, we just get out of the way; etc. (3) On the disputed assumption that trust involves a disposition to rely, trust has a valuable role to play in personal relationships. It enables us to rely on each other for things that matter to us. However, on our theory, faith has another valuable role to play. It enables us to continue relying on each other for things that matter to us despite difficulties.

${ }^{14}$ Morgan (2015), chapter 1, 5-7, passim.
} 
groups". 15 "Pístis/fides... is everywhere understood as a basic building block of societies, emerging from the need of individuals and groups to make and maintain relationships". ${ }^{16}$ Morgan also reveals how (2) pístis and fides were regarded as a "social virtue" which helped to glue people into cohesive social units. ${ }^{17}$ In addition, she shows how (3) pístis and fides were especially evident in times of relational crisis involving risk, fear, doubt, and skepticism. ${ }^{18}$ Furthermore, she describes how (4) various practices facilitated relationships of pistis and fides-e.g., written contracts between two parties, witnessed by a third party, a practice familiar to us todaywhich helps people to both continue relying on each other and to continue coming through for each other despite difficulties. ${ }^{19}$ She also explains how (5) in light of the value placed on pistis and fides, it is little wonder that they were elevated to gods in the Greek and Roman pantheons. ${ }^{20}$

Interestingly, Morgan also observes that the pístis and fides lexica appear on coins in ancient Greece and Rome, accompanied by shaking hands, fruit, vegetables, and grains, among other things indicative of peace, prosperity, and the public good. Here's such a coin (Fig. 1):

On the obverse side (left), we find the image of Vespasian, the Roman emperor between 69 and $79 \mathrm{CE}$, while on the reverse side (right), the words FIDES PVBL appear. Clasped hands symbolize mutual faith and faithfulness, as in a handshake agreement; moreover, soldiers cannot easily shake hands unless they lay down their weapons and thereby rely on each other not to use them. The winged caduceus is a symbol of successful trade and commerce, and the poppy and corn were important commodities of the time. On our theory, it is not the least bit surprising that such imagery would accompany the pistis and fides lexica; moreover, it can explain its plausibility. For, if faith is resilient reliance and faithfulness is resilient reliability, it is plausible that it was by pistis and fides (faith) that the public relied on the emperor and his allies for the social goods depicted, and that it was by pistis and

Fig. 1 Coin from Rome (73 $\mathrm{CE})$. Image retrieved from forumancientcoins.com (2020)

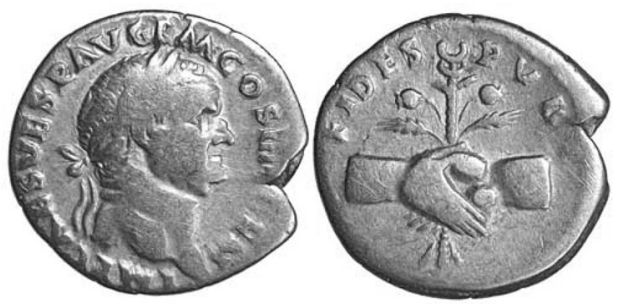

\footnotetext{
15 Morgan (2015), 6, 117-118.

16 Morgan (2015), 75.

17 Morgan (2015), 45, 118-119, 130, chapters 1-3 passim.

18 Morgan (2015), 17, 20, 22, 45, 63, 64, 74, 75, 78-79, 104, 117, 121, 124, 154, 170, 180-181, 209210, 502 .

19 Morgan (2015), 6, 20-21, 104-116, 181.

20 Morgan (2015), 83-85, 106-107, 127-135.
} 
fides (faithfulness) that the latter came through, resulting in the imaged peace, prosperity, and public good, despite difficulties both parties experienced in the relationship, e.g., taxation and conscription, and the occasional rebellion. ${ }^{21}$

Our theory accommodates and renders-plausible Pistis and Fides in the GrecoRoman World.

\section{Faith in contemporary secular contexts}

We now turn to positive correlations between faith and resilience in contemporary secular contexts - specifically, in politics, music, sports, biography, the movie industry, agriculture, and journalism — a datum we will call

Faith in Contemporary Secular Contexts Faith and resilience are widely positively-correlated in contemporary secular venues.

We haven't the space for thorough documentation, but what we document here exemplifies what we find many times over in these venues. In examining them, we find it useful to enter sympathetically into their context, and then to ask ourselves a question: if we were to inquire of these people whether what they express involves resilient reliance, would they respond, "No. No. Not at all"?

We begin with politics. In his Farewell Speech in February 2017, President Barack Obama commends faith to his fellow citizens: "faith in reason and enterprise, and the primacy of right over might," "faith in America and in Americans," and "faith... in the power of ordinary Americans to bring about change". Pretty clearly, he commends relying on these things and, in light of the preceding 2016 election, what he commended involved continuing to rely on them despite what he regarded as adversities presented by the incoming Trump administration.

Something similar occurs in Representative Hakeem Jeffries's closing remarks at Trump's impeachment trial in February 2020, when he repeatedly commended to all Americans that they "walk by faith," "faith in the Constitution; faith in our democracy; faith in the rule of law; faith in the government of the people, by the people, and for the people," which would help people "[t]hrough the ups and the downs, the highs and the lows, the peaks and the valleys, the trials and the tribulations of this turbulent moment". ${ }^{22}$

Likewise, in the aftermath of the 2020 election, President-elect Joe Biden and Vice-President-elect Kamala Harris repeatedly urged their supporters to "keep the faith," as the foundations of American democracy were shaken by those who sought to overturn the election results. "Faith in what?," we might ask them. No doubt their answer would be faith in the people integrally involved in the electoral process, Congress, the military, and other institutions of a representative democracy. Clearly enough, the faith to which they called Americans involves relying on these people despite difficulties posed by Trump and his allies. ${ }^{23}$

\footnotetext{
$\overline{21}$ Cf. Morgan (2015), 38, 77, 82-86, 129-130; see also, McKaughan (2017).

22 Jeffries (2020).

23 Google "Biden keep the faith" to view multiple occasions, including his Covid-19 anniversary speech (Biden, 2021). From the other side of the aisle, see Romney (2020), McConnell (2020), and Cipollone (2020).
} 
Next, consider faith expressed in popular music, especially its lyrical content, but also its performance, which we recommend for full effect. We focus on just one example, what MLK named "the unofficial anthem of the Civil Rights Movement," a song he "often used to get people marching or to calm and comfort them," Curtis Mayfield's People Get Ready. ${ }^{24}$ It was the Impressions greatest hit, written when resistance to the Civil Rights Movement was dug in, recorded in 1964, and released in 1965.

People get ready, there's a train comin'. You don't need no baggage; you just get on board.

All you need is faith to hear the diesels hummin'. You don't need no ticket; you just thank the Lord.

People get ready, there's a train to Jordan, picking up passengers, coast to coast. Faith is the key, open the doors and board them. There's hope for all among those loved the most.

There ain't no room for the hopeless sinner, who would hurt all mankind just to save his own. Have pity on those whose chances grow thinner, for there is no hiding place against the kingdom's throne. [Chorus].

In African-American culture from the early nineteenth century on, railroads image escape and hope; hence, the naming of the Underground Railroad. ${ }^{25}$ Mayfield taps into this hopeful image, connecting it to another, the River Jordan, through which the Israelites passed en route to the Promised Land away from Egypt's oppression. In the 1950s and early 1960s, with the South exerting states' rights over federal law, it was not a foregone conclusion that the racism buried in judicial, penal, and lawenforcement institutions would be exhumed, just as it is not now, six-plus decades later.

In the song, Mayfield identifies faith as "the key," both to hearing the "train comin" and to responding appropriately, i.e., opening the doors and getting on board, relying on it to take them "to Jordan" and the justice imaged by "the kingdom's throne". Of course, as Mayfield well knew, the Movement faced resistance from without, from "the hopeless sinner who would hurt all mankind just to save his own". Moreover, as MLK indicates in his writings from 1964 to 68, resistance stiffened after his 1963 I-have-a-dream speech. Further, the Movement struggled from within to maintain nonviolent protest among its members. Against this background, Mayfield calls on people to hear and act by faith, thereby enabling themselves to cope with internal strife, to defy Jim Crow, and to overcome a thousand other obstacles thrown up by the pitiable, those who reject "the kingdom's throne," those who seek the "hiding place" in slavery's long insidious shadow. ${ }^{26}$

\footnotetext{
24 Erickson (2015).

25 Kornweibel (2010).

26 Other pop songs linking faith and resilience: (1) John Hiatt's Have a Little Faith in Me, released in 1987, written after "a trail of wreckage," personal and professional, wrought by his drug and alcohol addiction (Hiatt (2019); cf. Joe Cocker's (1997) Berlin cover); (2) Have a Little Faith, written by Jim Tullio and Jim Weider, and performed by rhythm-and-blues icon Mavis Staples; (3) Faithful, performed by rapper Michael Ray Nguyen-Stevenson, aka Tyga.
} 
Unsurprisingly, faith shows up in the world of sports. In this connection, recall "The Shot". At the end of the fourth quarter of Game 6 of the 1998 NBA Championship, Michael Jordan stole the ball, with his team, the Chicago Bulls, trailing by one point. Moments later, he buried the game-winner. During the ensuing oncourt mayhem, the camera caught him clutching his coach, Phil Jackson, declaring "I had faith! I had faith!" Faith in what? Himself? His teammates? The Lord above? Well, whoever it was, Jordan relied on them in the face of a serious challenge- the Stockton-Malone Utah Jazz- to take a sixth championship, the second three-peat (Fig. 2). ${ }^{27}$

Next, consider Nelson Mandela's description of what kept him going during his 27 years of imprisonment in apartheid South Africa:

I am fundamentally an optimist. Whether that comes from nature or nurture. I cannot say. Part of being optimistic is keeping one's head pointed toward the sun, one's feet moving forward. There were many dark moments when my faith in humanity was sorely tested, but I would not and could not give myself up to despair. That way lay defeat and death. ${ }^{28}$

Mandela notes here that it was his "faith in humanity"-faith in the humanity of the international community and even his oppressors, we learn - that pulled him through "many dark moments," that kept him from giving in "to despair" and "defeat and death".

The theme of faith in humanity appears in Chloe Zhao's acceptance speech at the 93rd Academy Awards (2021), for best director, for Nomadland, the story of a woman, played by Frances McDormand, who, in her ' $60 \mathrm{~s}$, loses everything after the Great Recession of 2007-2009, and sets out on the road, living in her van, searching for, and occasionally finding, seasonal work. After the customary thank-you's, Zhao recounts a Chinese poem she memorized as a child whose first words were "people at birth are inherently good". She continues:

[T] hose six words had such a great impact on me when I was a kid and I still truly believe them today, even though sometimes it might seem like the opposite is true.... So, this [award] is for anyone who has the faith and the courage to hold on to the goodness in themselves and to hold onto the goodness in each other, no matter how difficult it is to do that. And this is for you, you inspire me to keep going. Thank you. ${ }^{29}$

\footnotetext{
${ }^{27}$ Google "faith" and the name of your favorite sports team. You'll find players, coaches, sportswriters, and/or fans expressing continued reliance on others despite difficulties. See, e.g., Silver (2015), Dutta (2021), and Daily Mail (2021).

${ }^{28}$ Mandela (1994), Kindle Locations 6561-6563.

${ }^{29}$ Zhao (2021).
} 
Here Zhao expresses faith in the goodness of others, and herself, a faith that, in part, enables her "to keep going when things get hard," "even though sometimes it might seem like the opposite is true," and "no matter how difficult it is" to "hold on" to that goodness. ${ }^{30}$

The Editorial Board of Agweek describes what they find in those who work in the ag-sector. "It goes by many names," they write: "act of faith and leap of faith, among them". They continue:

Farmers aren't the only ones who made it, of course. The businesspeople who sold them seed, fuel, chemicals, fertilizer and more, the bankers who lent them money, the agronomists and other ag-sector employees who provide expertise and labor all have a stake of some sort in [it].... Ranchers also require faith.... If the weather doesn't cooperate, they won't have enough hay and pasture to feed their livestock. The drought of 2017 provided an awful reminder of that.... 31

These authors find that the faith of the people of the ag-sector is what keeps them relying on each other for expertise, funding, labor, and products - and on Nature's cooperation-despite difficulties and setbacks such as the 2017 drought.

The Aspen Weave Project, founded by journalist David Brooks, documents how Americans are more united than divided, contrary to what we might suppose. Brooks and his researchers interviewed "weavers," people intent on remaining in urban neighborhoods, creating connections, bridging divides, and building relationships. Interviewer Charlayne Hunter-Gault asks him how the weaver-solution to fragmentation and polarization will continue. Having noted how neighbors showed up for each other in the first few weeks of the Covid-19 pandemic, and the collective outrage at the murder of George Floyd, Brooks replies:

When I look at the marches, when I look at the people I speak to through the Weave Project, when I look at the people I interview through my journalism, I just see such a desire for a new era. And such a sense that this is a portal to a different future. I have faith in that. ${ }^{32}$

At the end of an op-ed covering the same ground, Brooks writes:

We also need to have faith in each other. Right now, millions of people all over are responding to the crisis we all feel. We in the news media focus on Donald Trump and don't cover them, but they are the most important social force in America right now. Renewal is building, relationship by relationship, community by community. It will spread and spread as the sparks fly upward. ${ }^{33}$

\footnotetext{
30 See Preston-Roedder (2013) for more on resilience and faith in humanity.

31 Agweek (2018).

32 Hunter-Gault (2020).

33 Brooks (2019).
} 
Fig. 2 Michael Jordan to Phil Jackson. Image retrieved from Hehir (2020), Episode 10, 18.49

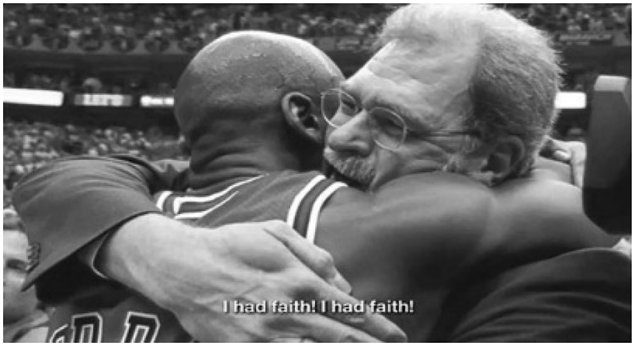

Brooks says he has faith in the marchers and weavers, faith in their desire for a new era, faith in their sense that we are at "a portal to a different future". And, he says, "We also need to have faith in each other" to build that "different future" "relationship by relationship, community by community". Note that Brooks expresses faith as something that disposes us to rely on each other for "renewal" and other goods in the face of the all-too-familiar forces that would fling us apart.

Our theory of faith accommodates and renders-plausible Faith in Contemporary Secular Contexts. Importantly, we have not found in this source any instance of faith negatively correlated with resilience.

\section{Faith and resilience in religious contexts}

We now turn to religious contexts. While there are many different religious contexts, and a variety of faith-data in each of them, we will focus on expressions of pístis in the New Testament and ' $\breve{e}$ ûnāh in the Hebrew scriptures, the role of faith in the biblical themes of covenant and salvation, the lives of exemplars of faith in God in the Abrahamic tradition, and the lives of ordinary people of Abrahamic faith today.

\section{Pístis in the New Testament}

Several NT authors closely associate pistis and relying despite difficulties. We focus on the Synoptics and the Epistles.

In Mark's Gospel, Jesus explicitly commends someone's pístis three times, and on each occasion their most salient feature is relying despite adversity. Consider the unnamed woman with a hemorrhage, whom we will call "Veronica," in accordance with tradition. ${ }^{34}$ A synagogue leader named "Jairus" begs Jesus to come to his home to heal his dying daughter. Jesus consents and, as they walk together, a "large crowd" follows. At the rear is Veronica, who suffers from continuous uterine bleeding, unable to find a cure, and getting worse. Mark says she knew of Jesus's ability to heal. So, she weaves her way through the crowd, which is "pressed in on him," trying to get close. When she does, she secretly touches his cloak from behind and,

34 Mark 5:21-34. 
immediately, she is healed. Jesus senses that "power [has] gone forth from him," stops, pivots, and asks who touched him. The disciples balk at the question, given the proximity of the crowd. Jesus persists. Eventually Veronica falls down before him, "in fear and trembling," and tells him "the whole truth". As she finishes, he says: "Daughter, your pistis has made you well; go in peace and be healed of your disease".

The narrative emphasizes how Veronica relied on Jesus to heal her despite the fact that, as Mark says, "[s]he had endured much under many physicians and had spent all that she had; and she was no better, but rather grew worse". Her medical condition, her feeling of hopelessness induced by twelve years of medical failure, her getting worse, and her anemia-burdened struggle in approaching Jesus through the "large crowd" were all difficulties she overcame to get to him. ${ }^{35}$ Moreover, the purity laws prohibited an unclean woman from mixing with the crowd and from touching non-familial men. In reaching out to Jesus, relying on him to heal her, she overcame her internalization of these prohibitions and fear of reprisal. She may have also overcome a Leviticus-inspired fear that in touching a holy man she would die. $^{36}$

Jesus knew of her relying on him despite difficulties when, as she finished her story, he commended her pistis. Indeed, this feature seems the most evident fact about her. So, it seems plausible that Jesus fastened on it when he commended her pístis. The same goes for the characters in two other stories in which Jesus commends someone's pistis: blind Bartimaeus and the friends of the paralytic. ${ }^{37}$

Very briefly, six considerations underscore the centrality of this feature to pistis in Mark's Gospel. First, as we just indicated, in three stories in which Jesus commends someone's pístis, he fastens on their relying on him, despite adversity, to heal on their behalf. Second, in no other story does Jesus commend someone's pístis; relying despite difficulties always attends his commendation. Third, on four other occasions when Mark uses the pistis lexicon, he twice associates this feature with pístis - in the stories of Jairus and the father of the demon-possessed son-and he twice associates its lack with a lack of pistis - in the disciples' lack of pistis in him on the stormy sea and their lack of pístis in God to heal the demon-possessed boy. ${ }^{38}$ Fourth, in two other stories - the Syrophoenician woman and the woman who anoints Jesus at Bethany-Mark does not use the pístis lexicon but when Matthew and Luke, who relied on Mark as a source, retell these stories, they see them as exemplars of pístis, having Jesus explicitly commend them for their pístis and, when he commends them, he plausibly fastens on relying despite difficulty. ${ }^{39}$ Fifth, Mark

\footnotetext{
35 Cf. Williams (1994), 116; Black (2011), 104, 149; Marshall (1989), 104; Marcus (2000), 357.

36 Cf. Kinukawa (1994), 45; Marshall (1989), 107; Black (2011), 141; Marcus (2000), 357-358; Miller (2004), 158.

37 Mark 10:46-52; Mark 2:1-12.

38 Mark 5:21-24, 35-43; 9:14-29; 4:40; 9:19.

39 Mark 7:24-30, 14:3-9; Matthew 15:21-28 and Luke 7:36-50.
} 
encourages us to view Jesus as a role-model. When we do, we see him modeling a pistis closely associated with this feature, e.g., in his prayer in Gethsemane and his execution on Golgotha, about which we'll have more to say below. ${ }^{40}$ Sixth, according to Morgan, in the Greco-Roman world surrounding the early churches and from which they mainly derived its understanding of pístis, it centrally involves relying on others-especially, she repeatedly notes-in the face of risk, fear, doubt, and skepticism. As such, pístis kept people together in times of crisis. ${ }^{41}$ These six points together suggest that, in the words of Christopher Marshall, the foremost expert in the English-speaking world on pistis in Mark's Gospel, "Without doubt, the leading characteristic of Markan faith is sheer dogged perseverance" in relying on Jesus and/ or God. ${ }^{42}$

Something similar can be said for pístis exhibited in Matthew's Gospel. Consider the story of the Canaanite woman. ${ }^{43}$ She approaches Jesus: "Have mercy on me, Lord, Son of David; my daughter is tormented by a demon". But he doesn't answer her, and his disciples urge him to send her away. Eventually, Jesus does answer: "I was sent only to the lost sheep of the house of Israel". But she persists, begging him on her knees: "Lord, help me". He answers again: "It is not fair to take the children's food and throw it to the dogs". But she doesn't give up: "Yes, Lord, yet even the dogs eat the crumbs that fall from their masters' table". "Then Jesus answered her, 'Woman, great is your pístis! Let it be done for you as you wish.' And her daughter was healed instantly". Plausibly enough, Jesus commends her for relying on him to heal her daughter; further, she overcomes several obstacles in doing so: the historical hostility between Jews and Canaanites, the culturally-built barrier between men and women, Jesus's initial silence, the disciples' animosity, and both of Jesus' insults. And her pístis is vindicated.

The narrative structure in these two stories is typical of miracle-stories in the Synoptics: someone has a need, they or a proxy rely on Jesus to help, they continue to rely despite difficulty, Jesus recognizes their pístis, he performs a miracle, and they or others respond. ${ }^{44}$ A similar analysis of many of these stories throughout the Synoptics is arguably justified.

The Epistles also closely associate pístis with relying despite difficulties. James says pístis in the face of opposition is a mark of maturity. ${ }^{45}$ Paul encourages the Corinthians to "stand firm in your pístis". ${ }^{46} 2$ Thessalonians praises Jesus-followers "for your steadfastness and pistis during all your persecutions and the afflictions that you are enduring". ${ }^{47}$ Colossians commends people for "your morale and the firmness of your pístis in Christ". ${ }^{48} 1$ Peter connects this feature with authentic faith: "for a

\footnotetext{
40 Mark 14:32-42; 15:21-37.

41 Morgan (2015), 7, 117, 120, 121.

42 Marshall (1989), 237. For more on these six points, see Howard-Snyder (2017a).

43 Matthew 15:21-28.

44 Ryken (2016), 56-57.

45 James 1:2-4.

46 1Corinthians 16:13.

472 Thessalonians 1:3-4.

48 Colossians 2:5.
} 
little while you have had to suffer various trials, so that the genuineness of your pistis...may be found to result in praise and glory and honor...". ${ }^{49}$ Hebrews compares continuing in pístis to running a race: "let us run with perseverance the race that is set before us, looking to Jesus the pioneer and perfecter of our pistis". ${ }^{50}$ Indeed, Hebrews connects pístis and perseverance so tightly that, according to Dieter Lührmann, in it "pístis means above all 'perseverance,' the holding fast to a promised hope; it is threatened by apistia as the loss of such a hope". ${ }^{51}$ Notably, the famous characterization of pístis in Hebrews 11:1 as "the substance [hypostasis] of things hoped for, the evidence [elenchus] of things not seen," is both preceded and followed by material that emphasizes relying through difficulties and explicitly contrasts pístis with "shrinking back". 52

The NT data adduced here strongly suggests an important faith-datum:

Pístis in the NT According to many NT authors, pístis often involves relying on Jesus and/or God despite adversity.

Our theory accommodates and explains Pístis in the NT. We now turn to expressions of 'ěmûnāh in the Hebrew Scriptures.

\section{Emûnāh in the Hebrew scriptures}

Cognates in the Hebrew 'ĕmûnāh lexicon-which derive from the root 'aman (sometimes abbreviated'mn) — point to stability, firmness, loyalty, constancy, and reliability, meaning 'to rest secure', 'to be firm'. ${ }^{53}$ Firm with respect to what, we might ask? As it turns out, the 'emûnāh lexicon points to firmness in faithfulness and in faith, depending on how its verb form,'aman, is conjugated.

The passive niphal verb form, ne'ěmān, is most often glossed "to be faithful" or "to endure," and thus the participle means "enduring, lasting," and when applied to persons "stable, reliable". ${ }^{54}$ Deuteronomy represents "the faithful (ne' émān) God who maintains covenant loyalty with those who love him and keep his commandments, to a thousand generations," while a Psalm says the covenant itself "will stand firm (ne'ěmān)". 55 The niphal can also express someone's faithfulness to God, as when Hosea says "Judah still walks with God, and is faithful (ne' ’̌mān) to the Holy One," and Nehemiah describes why Abraham pleased God: "a faithful (ne'ěmān) heart" in response to God. ${ }^{56}$

\footnotetext{
49 1 Peter 1:3-9.

50 Hebrews 12:1-2; cf. 2 Timothy 4:7-8.

51 Lührmann (1992), 755.

52 Hebrews 10:36-39; cf. 12:1-4ff, 16:12. For more on the NT data, see McKaughan \& Howard-Snyder (forthcoming).

53 Sovran (2014), 91; cf. Jepsen (1977), 322-323.

54 Brown et al. (1977), 52-53; Moberly (1997), 427-433; Jepsen (1977), 322-323.

55 Deuteronomy 7:9; Psalm 89:28.

56 Hosea 11:12; Nehemiah 9:8. Jubilees 17-23 celebrates Abraham for his ne' ĕmān (Swanson (2014), 701). Cf. 1 Samuel 2:25, 3:20; Psalm 101:6.
} 
In contrast, the active hiphil verb form, he'emin, expresses action, "to be firmly set in/on something, to hold firm" and "is used especially of a person or his word: to build steadfastly on someone, or to rely on his word," as in "to stand firm," "to trust," "believe in," or "place confidence in". ${ }^{57}$ Isaiah portrays God as laying a stable foundation on which one can rely: "thus says the Lord God, See, I am laying in Zion a foundation stone.... 'One who trusts (he'emin) will not panic'". ${ }^{58}$ John Barton writes that "he'emin has as its main meaning reliance on the reliable" and he favorably quotes Egon Pfeiffer, who speaks of "the active side" of he'emin as "holding secure' - the person relies on the security, faithfulness, and reliability of God, and lives accordingly". ${ }^{59}$ The active hiphil characterizes Abraham's exemplary response to God: "And he he' ěmîn [believed, relied on, or "faithed," to adopt an anthimeria] the LORD; and the LORD reckoned it to him as righteousness". 60

Interestingly, the Hebrew noun 'ĕmûnāh consistently connotes faithfulness rather than faith in each of its 49 occurrences in the Hebrew scriptures, ${ }^{61}$ with one possible-though controversial-exception: "Look at the proud! Their spirit is not right in them, but the righteous live by their 'ěmûnāh," often translated "faith". ${ }^{2}$ Edmund Perry notes:

The Gordian knot of the statement ['the righteous live by their faith'] is the word 'emuna, translated "faith" here, but elsewhere and more often translated "faithfulness". Is it the reliance or the reliability of the righteous which is intended in this passage ? $^{63}$

Or both at once? After all, as Perry continues, the 'ĕmûnāh-response to God involves both relying and faithfulness:

[T]he Old Testament does not set trust and obedience in contrast to each other as separate ways of satisfying the demands of God.... [T] 'ěmûnāh in a way that would be pleasing to God, as in Jeremiah 5:1, must seek to both trust and obey God. ${ }^{64}$

In a famous wordplay, Isaiah issues the LoRD's warning to King Ahaz, using first the active hiphil and then the passive niphil form of the verb he'emin. Barton comments: "The NRSV renders, 'If you do not stand firm in faith (he'emin), you shall not stand (ne'ěmān) at all,' in an attempt to capture the pun: the sense is that those who do not rely on God will not be held firm by him". ${ }^{65}$ Similarly, in 2 Chronicles we find: "he'emin the LORD your God and you will ne'ěmān; he'emin his prophets

\footnotetext{
57 Healey (1992), 745; Jepsen (1977), 322-323; Barton (unpublished), 4; cf. Brown et al.(1977); Clines (1993).

58 Isaiah 28:16; cf. 53:1. Paul quotes this twice, Romans 9:33 and 10:11; cf. Betz (1990), 443-444.

59 Barton (unpublished), 8-9; Pfeiffer (1959).

60 Genesis 15:6. Barton (unpublished), 4.

61 Clines 1993; Brown et al.(1977).

62 Habakkuk 2:4; quoted by Paul from the LXX as pístis, in Galatians 3:11 and Romans 1:17.

63 Perry (1953), 252.

64 Perry (1953), 255.

65 Isaiah 7:9; Barton (unpublished), 6.
} 
[and you will succeed]," with the JPS Tanakh using "stand firm" for the passive niphil and "trust firmly" for the active hiphil. ${ }^{66}$

Bernhard Anderson sums it up well: "In the Old Testament faith is steadfast reliance on God amid the uncertainties and insecurities of life". ${ }^{67}$ It appears, therefore, that our foray into the Hebrew Scriptures reveals another faith-datum, which, following Anderson, we can put like this:

'Emûnāh in the Hebrew Scriptures. Insofar as the 'ĕmûnāh lexicon expresses faith, it expresses continuing to rely despite difficulties.

Our theory accommodates and explains this datum. ${ }^{68}$

\section{The biblical themes of covenant and salvation}

For many people, no theory of faith is worth its salt unless it can handle the biblical themes of covenant and salvation and, specifically, their relation to faith. We agree. After all, in the Abrahamic tradition, covenant and salvation are closely associated with faith, although exactly how they are related varies extensively within the tradition. We have then two more items of faith-data.

Covenant In the Abrahamic traditions, faith is somehow central to covenants, specifically the stories of the covenants between God and people.

Salvation. In the Abrahamic traditions, faith is somehow central to salvation, specifically the stories of salvation of people by God.

We begin with Covenant.

In the ancient Near East, covenants emerged as a way of extending familial relationships. They "functioned as a legal means to integrate foreign individuals or groups," and to receive kin-in-law, into a network of privileges and obligations ordinarily reserved for blood-relations. ${ }^{69}$ As in many human societies, in cultures of the ancient Near East, kin tended to rely on each other, and to come through for each other, in ways that bound them together, ways that were extended to others via oaths and rituals that formalized expectations to the relationship. In this cultural context Semitic tribes took it that God and people entered into covenants.

In the Hebrew scriptures, God sometimes unilaterally-and without explicitly laying down any conditions - enters into covenants, as when God vows to Noah and humanity more generally never again to destroy life on earth by a flood, or God promises to give Abraham descendants and to bless all nations through them. ${ }^{70}$ However, implicit in these unilateral covenants are obligations on the part of humanity and Abraham, e.g., to never again sink to the level of pre-Noahic depredation, or to follow God's instructions. Sometimes these obligations are made explicit, and the

\footnotetext{
662 Chronicles 20:20.

67 Anderson (1999), 3.

${ }^{68}$ For more on the Hebrew-scriptures data, see McKaughan \& Howard-Snyder (forthcoming).

${ }^{69}$ Hahn (2009), 3; cf. 28.

70 Genesis 9:8-17; Genesis $12: 1-3,7 ; 13: 14-17 ; 15: 4-21 ; 17: 4-16 ; 22: 15-18$.
} 
covenant is explicitly conditional, holding only so long as the obligations are kept, as in God's covenant with the nation of Israel, which occurs after God leads them out of slavery in Egypt and promises them protection and prosperity on the condition that God alone is their God, and they live in accordance with the Torah. The familial character of God's covenant with Israel is evident in the recurring declaration "I will be your God and you will be my people". 71

Ideally, God relies on Israel to keep its terms of the covenant, and Israel comes through for God; and, ideally, Israel relies on God to keep God's terms of the covenant, and God comes through for Israel. In truth, however, the story of Israel in the Hebrew scriptures falls short of the ideal. For while the story has God continuing to rely on Israel throughout the centuries despite its fits and starts at coming through, and it has God continuing to come through for Israel despite its fits and starts in relying on God, by contrast it has Israel relying on God in fits and starts despite God's continuing to come through for Israel, and it has Israel coming through for God in fits and starts despite God's continuing to rely on Israel. This is the basic storyline of the covenant between God and Israel in the Hebrew Scriptures. (What we've said here applies, mutatis mutandis, to God, the Church, and the "new covenant".)

Clearly enough, since, on our theory, faith is resilient reliance, it accommodates and explains the plausibility of Covenant. ${ }^{72}$

Now we turn to Salvation.

On the salvation stories of the Abrahamic traditions, we humans tend to fail in multiple ways: we don't live up to our ideals, we seek our own power, we prefer selfinterest over the common good, we squander our talents, we neglect to steward creation well, and by acts of commission and omission we thwart the establishment of a just and harmonious global community. These and other failures are at odds with God's purposes, resulting in alienation from God and each other. At our best, we are aware of our failings and we own them, with regret and an intention to improve. But improvement is difficult, fraught with setbacks, greed, malaise, uncooperativeness, disrespect, and a hundred other things, as a look at any history book, or the nightly news, or our own lives will confirm. Left to our own devices, failure is not only our past-it is our future. ${ }^{73}$

\footnotetext{
71 Jeremiah 7:23, passim.

72 Objection If God has faith in Israel to keep the covenant, then, if our theory is correct, God resiliently relies on them to keep the covenant. But God knows what Israel will do on that score, in which case it is false that God resiliently relies on them to keep the covenant. After all, if God knows Israel will (ultimately) keep the covenant, what sense is there in saying God resiliently relies on Israel to do so? As an anonymous reviewer put it, "since there is no risk or uncertainty with [God's] knowledge, where is the space for resilience?" Our theory entails a contradiction. Reply (1) With biblical scholars from all perspectives, we frown on reading perfect being theology into the text. (2) On Open Theism, God doesn't know that Israel will keep the covenant; there's the desired "space for resilience". (3) Even if Open Theism is false, "space for resilience" can arise from non-evidential challenges. Suppose God has faith in Israel to keep the covenant, and suppose God knows that Israel will keep it. Then, evidential challenges to relying on Israel to keep the covenant will not arise for God. But, as Israel's keeping the covenant waxes and wanes, God may well resiliently rely on Israel to keep the covenant in the face of other challenges, e.g., disappointment, anger, a sense of betrayal, etc., all in response to their unfaithfulness, which is what we actually find in the text.

${ }^{73}$ For a more detailed display of these and other failures, see Hudson (2021).
} 
Fortunately, say these traditions, God has not left us to our own devices but has rather provided a path to reconciliation. Naturally, these broad traditions and their sub-traditions tell different stories about what, exactly, that path is and how to walk it, individually and collectively. Still, they all share the idea that God draws us into a relationship of mutual faith and faithfulness, calling us to rely on the resources God provides-whether that involves obeying the Torah, or receiving God's grace and following Jesus, or submitting to Allah-and continuing to rely on those resources despite difficulties. So it is, these traditions say, we may, eventually, undo the alienation that plagues us and become reconciled with God and each other.

On our theory, faith is resilient reliance, and so it accommodates Salvation and renders it plausible. Our theory also helps us to understand why these traditions would value restoration of a flourishing relationship of mutual faith and faithfulness between God and people, while leaving it open how such reconciliation might be accomplished.

\section{Exemplars of faith in God}

We now turn to expressions of faith in the lives of exemplars of faith in God. Different traditions offer different exemplars. We will focus on two: Abraham and Jesus. ${ }^{74}$ Moreover, we will zero-in on one kind of difficulty: intellectual doubt. Of course, this is not the only kind of difficulty exemplars face. As with everyday people of faith, exemplars struggle with emotional, social, and other sorts of difficulty. But we see a benefit to focusing on doubt. For, everyday people of faith sometimes struggle with doubt, and they might find comfort in learning that, in this respect, they struggle in the company of exemplars of faith in God.

We start with Abraham.

Abraham's story begins in Genesis 12, when God visits him and commands him to leave his family and homeland, promising to make of him a great nation that will bless the world. According to Raymond Brown, "Abraham recognized that in responding to God's demands he must place his entire reliance on the God who not only called him, but would guide his steps, meet his needs and prepare his future". 75 We agree. In obeying the command, Abraham not only relies on God to make a great nation of him, and to bless the families of the earth through him, he also relies on God as one with the standing to issue the command in the first place, as one who has in view his own good and the good of his immediate family, and as one who will keep the promise even as they travel through hostile territory.

While the narrative arc of Abraham's story has him relying on God to keep the promise, he sometimes seems not to rely on God as much as he might have, which suggests that, lurking in the background, lies some doubt about whether God will come through. This tension between the reliance to which God calls Abraham and the intellectual difficulty Abraham experiences in relying on God arguably drives

\footnotetext{
74 On Mother Teresa as an exemplar of faith whose faith perseveres amidst doubt, see McKaughan (2018).

75 Brown (1982), 204.
} 
the narrative and keeps readers riveted. The narrative highlights, with striking frankness, ways that Abraham falters in his reliance on God, ways plausibly connected with doubt about whether God will keep the promise, through the decades of waiting for God to make good on it. ${ }^{76}$

Indeed, right from the start, when God calls Abraham, he-already 75 years old and well past his prime-hedges his bets. God says, "Go from your country and your kindred and your father's house to the land that I will show you," but Abraham brings some kindred along, notably his much younger nephew Lot-plausibly in the hope that Lot will produce an heir should the aging Abraham prove not up to the task. $^{77}$

Moreover, both immediately before and immediately after Abraham is so memorably commended for putting his faith (he' ̌̌mîn) in God, in 15:6, he expresses doubt. He points out the obvious fact that "You have given me no offspring" and requests reassurance of the promise: "O Lord GOD, how am I to know that I shall possess [the land]?"78 One who has no doubt needs no reassurance. Instead, the narrative explicitly ties, on the one hand, Abraham's taking of Eliezer as his heir to, on the other hand, both his continued childlessness and his lack of confidence in response to God's reassurance that Abraham need not fear that God will fail to keep the promise. ${ }^{79}$ And, not long after Abraham's faith is commended, "a deep and terrifying darkness descended upon him," prompting further reassurances from God. ${ }^{80}$ God would not have needed to provide these reassurances if Abraham had not been in considerable doubt.

In addition, both Sarah and Abraham have difficulty believing that the heir will come through her womb, and difficulty relying on God to deliver in this way. That's why Abraham takes Hagar as a mistress, who finally bears Ishmael when, as the narrative calls to our attention, Abraham is 86 years old. ${ }^{81}$ Fathering Ishmael also bespeaks doubt.

Further, Abraham twice tells foreign leaders that Sarah is his sister rather than his wife, once before and once after God's specific promise (in Genesis 17) that Sarah will bear a son, Isaac, and that he will be the heir. ${ }^{82}$ God afflicts Pharaoh with plagues and threatens King Abimelech with death, for taking her into their houses. In neither case is it clear that Abraham relies on God to protect her; instead, he hatches his own plan of protection. ${ }^{83}$ As Walter Brueggemann puts it, "even this model figure of faith was tempted to form an immediate alternative future of his own making". ${ }^{84}$ Making his own plans likewise bespeaks doubt.

\footnotetext{
76 Cf. Stump (2012); Pace and McKaughan (2020).

77 Genesis 12:1, emphasis added, 4-5.

78 Genesis $15: 2-3,8$.

79 Genesis 15:1-3.

${ }^{80}$ Genesis 15:12-16.

81 Genesis 16:1-4, 15.

82 Genesis 2:10-20; 20:1-18.

83 Genesis 20:11.

84 Brueggemann (1986), 148.
} 
Further still, Abraham's laughter-in direct response to God's promise that Sarah will bear their heir-expresses serious doubt if not outright disbelief: "Then Abraham fell on his face and laughed, and said to himself, 'Can a child be born to a man who is a hundred years old? Can Sarah, who is ninety years old, bear a child?", ${ }^{85}$ Sarah laughs too, and then tries to hide it. ${ }^{86}$ After several lengthy and disturbing detours which prolong the fulfillment of the promise, the heir is born and given a name which commemorates that laughter: "everyone who hears will laugh with me". ${ }^{87}$ Isaac's name reminds the narrative audience that nothing is "too wonderful for the LORD". ${ }^{88}$ But not because doubt was uncalled for. After all, as Sarah eloquently puts it, "Who would ever have said to Abraham that Sarah would nurse children? Yet I have borne him a son in his old age". ${ }^{99}$ Yes, indeed; who would ever have said that? Again: the story bespeaks doubt.

Finally, in Genesis 22, Abraham's relying on God to keep the promise is put to a climactic test. God issues a command that will apparently destroy the basis for any lasting fulfillment of the promise: "Take your son, your only son Isaac, whom you love, and go to the land of Moriah, and offer him there as a burnt offering on one of the mountains that I shall show you". ${ }^{90}$ Now, whether Abraham's confidence in God at this point is maximal given their history together, or whether it isn't and he is nonetheless resolved to obey God-and to withhold nothing despite the apparent absurdity and immorality of the command-Abraham's relying on God to keep the promise despite numerous occasions of doubt has made his reliance complete. He raises the knife to sacrifice his son.

We have, therefore, on a plausible reading of Abraham's story, an exemplar of faith in God who, despite recurring doubt, continues to rely on God to keep the promise.

Now to Jesus.

Mark's Gospel presents Jesus as a role-model, and so we should expect Jesus to model something as important as faith, especially since, right at the outset, he proclaims that faith in the good news is what God desires from those who hear it. ${ }^{91}$ While we might explore how Jesus displays faith in the Twelve, as his disciples, we will focus instead on how he models faith in God, especially in Gethsemane and on Golgotha. $^{92}$

In Gethsemane, Mark exhibits Jesus' continued reliance on God as he comes to terms with how his execution will serve the new way in which God's rule will be established through him. Mark tells us that, after taking Peter, James, and John aside from the others in the garden, he became "distressed and agitated" at the prospect of

\footnotetext{
85 Genesis $17: 17$.

86 Genesis 18:11-15.

87 Genesis 21:6.

${ }^{88}$ Genesis 18:14.

${ }^{89}$ Genesis 21:7.

90 Genesis 22:2.

91 Mark 1:14-15.

92 Black (2011), 296; Rhoads (2004), 53-54. For a thorough treatment of Jesus as an exemplar of faith, see Tuggy (2017).
} 
the manner in which God's purposes involved him, so much so that he was "deeply grieved, even to death" ${ }^{93}$ Walking a bit away from them to pray, he throws himself on the ground, begging God to find another way, saying "Abba, Father, for you all things are possible; remove this cup from me".

To be sure, there is terror here but, plausibly, there is also doubt: doubt about the wisdom of God, doubt about what God's purposes require, and doubt about his own role in their fulfillment. Even so, Jesus leans into his faith in God's wisdom and purposes, thereby overcoming his terror and doubt, and resolving to do God's will no matter what: "yet, not what I want, but what you want". ${ }^{94}$ Notably, he returns to the three disciples to find them asleep and, after awakening and rebuffing them, he returns to pray alone where he "said the same words". Apparently, Jesus' struggle to continue relying on God despite his terror and doubt was not only intense but also recurrent.

Now to Golgotha. When Jesus was being crucified, Mark says that, near the end, "at three o'clock," Jesus screamed, "My God, My God, why have you forsaken me?"95 In the world of Mark's Gospel, Jesus has an explicit, conscious relationship of mutual faith and faithfulness with God, his "Abba, Father". ${ }^{96}$ And, here on the cross, Jesus expected God to be present to him in his hour of need-but his expectation is crushed. There is a sense of betrayal here, but there is also doubt, a "teetering on the edge between disillusionment and faith," as John Neuhaus puts it, doubt about God's care for and faithfulness to him. ${ }^{97}$ Yet, Mark presents Jesus as an exemplar of faith.

In doing so, Mark seems to say, "Look. This is what faith in God is like in circumstances such as these". You rely on God-to exercise wisdom, care, faithfulness, and love-and you continue to do so, despite your inability to understand, despite your feelings of betrayal, and despite the doubt induced by your situation.

So it is that, in Abraham and Jesus, we have another faith-datum:

Exemplars of Faith in God Exemplars of faith in God continue to rely on God despite a variety of struggles in doing so, even belief-cancelling doubt.

Our theory accommodates and explains the plausibility of this datum, notably with respect to two of the most prominent exemplars in the Abrahamic tradition.

\section{People of faith today}

People of faith today undergo a wide variety of religious struggles, e.g., a sense of alienation from God or their religious community, anger at God, fear, guilt, malaise, melancholy, shame, and spiritual fatigue, among other things. We will, however, continue our focus on doubt.

\footnotetext{
93 Mark 14:34.

94 Mark 14:36. Cf. Hartvigsen (2012), 470-471.

95 Mark 15:34.

96 Mark 14:36.

97 Neuhaus (2000), 232.
} 
So then: why should we suppose people of faith today sometimes struggle with doubt? Because three sources suggest as much.

First, there's your own experience as a person of faith (if such you be), as well as the experience of those you know personally (whether or not you are a person of faith). Haven't you or someone you know experienced doubt, even belief-cancelling doubt, at some point in your/their journey as people of faith? We have, as have many who have shared their stories with us. Yet here we are: continuing to rely on God in a variety of ways, despite our past or current doubt.

Second, there's the experience of people of faith you don't know personally but whose experience you have access to through other sources. In this connection, many religious leaders, e.g., rabbis, ministers, and imams, as well as others, e.g., counselors, therapists, and spiritual directors, report that the people of faith they serve sometimes experience severe doubt. Just ask them. One pastor we know reported that, on average, throughout a twenty-year career at several churches, two people a week sought doubt-related counsel. ${ }^{98}$ On a 2018 trip to Jordan, we spoke about faith and doubt to sixty professors and students, wondering aloud whether people of Muslim faith experience severe doubt, as Christians sometimes do. The response from the students was startling. They estimated that a third of their peers experience belief-cancelling doubt about the existence of Allah, among other things. ${ }^{99}$ An orthodox rabbi recently spoke to us of many devout congregants who experience belief-cancelling doubt. ${ }^{100}$ Or witness the scores of easily-googled selfhelp books that address doubting Christians, none of which would be written unless their intended audience experienced doubt severe enough to be addressed. In an unscientific sampling, students in our 2020 university seminar interviewed 20 adult evangelical Protestants. To our astonishment, 18 of 20 answered "Yes" to the question, "In the time that you have been a person of faith, have you ever been in doubt about whether God will come through with respect to what you put your faith in God for?," while 17 of 20, answered "Yes" to "In the time that you have been a person of faith, have you ever questioned the goodness or faithfulness or even the existence of God?," going on to describe their experiences in detail.

Of course, your own experience with people of faith, whether or not you know them personally, is anecdotal evidence. It would be desirable to have a more scientifically-based sample, so as to tell more reliably whether it is not unusual for people of faith to struggle with doubt, as our anecdotal evidence suggests. Fortunately, we have something like this already: sociological research on religious struggle and spiritual formation. This is our third source of evidence. According to Julie Exline and her team, being a person of faith bears a significant positive correlation to experiencing doubt at some time-whether mild, moderate, or severe-about God's love, justice, and existence, in addition to many other struggles involved in relying

\footnotetext{
98 On faith in God and intellectual doubt from a Christian perspective, see Howard-Snyder (2017b), McKaughan (2018), and Howard-Snyder and McKaughan (2021).

99 On faith in God and intellectual doubt from a Muslim perspective, see Aijaz (2018).

100 On faith in God and intellectual doubt from a Jewish perspective, see Lebens (2017, 2020, 2021).
} 
on God. ${ }^{101}$ Moreover, the most influential theory in developmental psychology of religion, James Fowler's theory of the stages of faith-which was initially based on interviews of 600 hundred people of faith, not to mention many more than that since then-recognizes continuing to rely on God in the face of challenges, including severe doubt, as a rite of passage for post-adolescent "mature" faith. ${ }^{102}$ Further, these bodies of research continue to grow, displaying similar results. ${ }^{103}$

These observations highlight the plausibility of another item of faith-data:

People of Faith Today Many ordinary people of faith today continue to rely on

God despite a variety of struggles in doing so, including intellectual doubt.

Our theory of faith accommodates and explains the plausibility of this datum. ${ }^{104}$

\section{The nature of faith's resilience}

Suppose faith is resilient reliance. We may well wonder: what is the nature of the resilience involved in faith, exactly?

Resilience has received a lot of attention from psychologists recently. However, when we turn to them for guidance, we're greeted with a dizzying array of options. Sisto et al. (2019) surveys 126 "constructs" in the literature (in English), between 2002 and May 2019. On all of them, resilience involves a response to challenges, but they differ in how they characterize the response. Most of them, however, when applied to people, emphasize one or more of the following properties.

Unperturbedness A disposition to remain (virtually) unchanged in response to a challenge.

Improvement A disposition to change for the better in response to a challenge.

Recovery A disposition to return to the state one was in after initially giving way to the challenge. ${ }^{105}$

None of these, however, is necessary for faith because each can be had without the other and having just one can be sufficient for the resilience required by faith.

By way of illustration, suppose Iman has faith in Allah to reward her submission. Then, on our view, she'll be disposed to rely on Allah to reward her, with resilience in the face of challenges to doing so. Suppose resilience is unperturbedness but not improvement or recovery. When life poses a challenge to relying on Allah to reward Iman, she's pretty much unfazed by it; it flows off her like water off a duck's back. She's not disposed to change for the better or to give way at all; she's just disposed

\footnotetext{
101 Exline et al. (2014).

102 Fowler (1981); Peck (1987); Seel (2012).

103 Cf. Ögtem-Young (2018), Pargament and Exline (2020), and van Tonergan et al. (2019).

104 Further evidence for this datum can be found in Christian hymns. See (1) "Alas, dear God, how weak my faith!," (2) "Oh, for a faith that will not shrink," (3) "From noon of joy to night of doubt," (4) "My faith still clings," (5) "I need, O Lord, a stronger faith," and (6) "He leads me still".

105 Cf. Malcolm and Scott (2021), 24, for a different take on this literature.
} 
to remain unchanged, continuing to rely in pretty much the way she always has. That, we submit, suffices for the resilience required by faith. Mutatis mutandis, the same goes for improvement and recovery: each suffices and neither of the other pair is required.

Something similar can be said for "constructs" in the neighborhood of resilience found in the psychological literature, for example grit, i.e., "perseverance and passion for long-term goals," spiritual fortitude, i.e., "a character trait enabling people to endure and make redemptive meaning from adversity through their sacred connections with God, others, and themselves," hardiness, i.e., "a pattern of attitudes and skills that provides the existential form of courage and motivation needed for learning from stressful circumstances, in order to determine what will be the most effective performance," persistence, i.e., "voluntary continuation of a goal-directed action in spite of obstacles, difficulties, or discouragement," and perseverance, i.e., "the ability to pursue one's goals to completion, even in the face of obstacles". 106 None is necessary for the resilience involved in faith, although each is sufficient. And the same goes for other items pointed to by English: endurance, firmness, steadfastness, tenacity, pluck, moxie, stick-to-itiveness, resistance, determination, doggedness, resolve, indefatigability, diligence, tirelessness, drive, stamina, pertinacity, mulishness, pigheadedness, stiffneckedness, obstinacy, etc.

We might go disjunctive here but, in our view, we would be better-served by positing that the resilience involved in faith is an unspecific general disposition to overcome challenges to continuing to rely on those in whom we have placed our faith, one that can be instantiated by any of a variety of different specific particular things, e.g., unperturbedness, improvement, recovery, grit, spiritual fortitude, hardiness, persistence, perseverance, and the like. For otherwise we will face what we might call the problem of particularity, i.e., the problem of identifying the resilience involved in faith with some particular thing that is sufficient but unnecessary to dispose us to overcome challenges to continuing to rely on those in whom we have placed our faith. So why do we pick "resilience" to point to this multiply-realizable unspecific general disposition? For its alliterative value: "resilient reliance" has a nice ring to it.

Other pistologists see a deep connection between faith and resilience, although none we know of have spilt much ink defending it, as we have here. ${ }^{107}$ Indeed, it's the rare bird who even pauses to consider the nature of faith's resilience. Finlay Malcolm and Michael Scott are a happy exception. Like us, they note the plurality of ways in which psychologists theorize about resilience, and they land on a way to unify that plurality. When we apply it to our theory of faith, the result is that, for you to have faith in someone for something is, in part, for you to be "disposed to resist,

\footnotetext{
106 Duckworth et al . (2007), grit; Van Tongeren et al. (2019), spiritual fortitude; Maddi et al. (2012), hardiness; Peterson and Seligman (2004), persistence; Kern et al. (2016), perseverance.

107 See, e.g., Buchak (2017), steadfastness; Matheson (2018), grit; Bishop (2007) and Jackson (2021) commitment; Wolterstorff (1990), firmness, tenacity, perseverance, steadfastness, resistance, resolve, and endurance.
} 
at least to some extent, factors that would [otherwise] lead you to cease" relying on them for it. ${ }^{108}$

This is a welcome suggestion. Even so, we prefer our proposal, for two reasons. First, we'd like to avoid any appearance of aligning ourselves with Freudian psychoanalytic theory, which talk of "resistance" might suggest. Second, and more importantly, their proposal faces the problem of particularity. For although resistance is sufficient to play the needed role in faith, it is not necessary. That's because it is possible to have faith in someone for something even though you are disposed to welcome-and not resist to any extent-factors that would otherwise lead you to cease relying on them for it. After all, you might be disposed to welcome-and not resist to any extent- the opportunity to confirm and strengthen your disposition to rely on them for it. Athletes with faith in their abilities or coaches who have faith in their teams, for example, might welcome-and not resist to any extent-contests and challenges in which their faith is tested. People of faith might likewise welcome analogous challenges. In our opinion, a theory of faith-or, more specifically, a theory of faith's resilience-should allow for this possibility.

\section{Summing up and looking ahead}

We began with a theory of relational faith according to which it is, fundamentally, resilient reliance, i.e., a disposition to rely with resilience in the face of challenges to doing so, and a theory of relational faithfulness according to which it is, fundamentally, resilient reliability, i.e., a disposition to come through reliably with resilience in the face of challenges to doing so. Moreover, we sketched a methodology for assessing a theory of faith based on a more general philosophical methodology. In addition, while pistological research remains to be done on the secular and religious contexts to which we have drawn attention, we submit that, since our theory posits faith's resilience, it can handle several items of plausible faith-data: Relying-andComing-Through, Neither-Fickle-nor-Flighty, Reciprocity, Role, Value, Faithlessness, Pistis and Fides in the Greco-Roman World, Faith in Contemporary Secular Contexts, Pístis in the NT, 'Emûnāh in the Hebrew Scriptures, Covenant, Salvation, Exemplars of Faith in God, and People of Faith Today. Further, we substantiated our claim that faith essentially involves resilience. Finally, when it comes to the nature of the resilience involved in faith, we argued for an unspecific general disposition that avoids the problem of particularity.

But there's plenty of work left to do. For example, we might wonder what competing theories of relational faith there are, and whether they can handle the faithdata we have presented as well as ours does. And we might investigate which better handles other faith-related data, better substantiates its theoretical claims, and better integrates with other things we know. In this connection, we might consider which more naturally extends to manifestations of faith other than relational faith, e.g., faith in ideals and causes, and propositional faith, and the life-unifying-and-structuring

$\overline{108 \text { Malcolm and Scott (2021), } 24 .}$ 
faith exhibited by those who are people of faith, orientational faith, and which more plausibly unifies these diverse manifestations of faith under a theory of faith simpliciter, something that is faith, rightly and strictly speaking, of which these are its manifestations. And we might inquire after which more successfully steps up to the plate of an evidence-based empirical psychology of faith, e.g., by providing valid measures that can be used to confirm or disconfirm differing predictions, or by shedding light on how faith is related to other phenomena of interest. And we might assess which more plausibly solves the problems of faith, e.g., the value problem, the problem of faith as a virtue, the problem of faith and reason, and the problem of the trajectory, among others. ${ }^{109}$ And we might investigate which provides new plausible solutions to problems in other areas of philosophy, whether in the philosophy of religion, epistemology, ethics, political philosophy, or elsewhere. Finally, we might explore which provides a more useful theoretical framework for clinical applications, e.g., in therapy, counseling, and spiritual direction.

As we said, there's plenty of work left to do. In any event, we hope that what we've said is at least somewhat on target. For, if it is, we'll be that much closer to understanding the nature and value of the faith in God to which the Abrahamic traditions call people, as well as the nature and value of the faith we find in human-human relationships of mutual faith and faithfulness. ${ }^{110}$

Funding John Templeton Foundation (61106).

\section{References}

Adams, R. M. (1999). Finite and infinite goods.

Agweek. (2018). Our collective leap of faith. Retrieved Sept 11, 2021, from https://www.agweek.com/ opinion/4461503-our-collective-leap-faith.

Aijaz, I. (2018). Religious doubt, Islamic faith, and the skeptical Muslim. Islam: A contemporary philosophical investigation, Chapter 6. Routledge.

Alston, W. P. (1996). Belief, acceptance, and religious faith. In J. Jordan \& D. Howard-Snyder (Eds.), Faith, freedom, and rationality (pp. 3-27). Rowman \& Littlefield.

Anderson, B. (1999). Contours of Old Testament theology. Augsburg Fortress.

Audi, R. (2011). Rationality and religious commitment. Clarendon.

Barton, J. (Unpublished). Faith in the Hebrew bible. Content to be incorporated into Barton, J. (2022). Translating the Bible. Penguin.

Beck, J. (2013). Why we can't say what animals think. Philosophical Psychology, 26, 520-546. https:// doi.org/10.1080/09515089.2012.670922.

Bengson, J., Cuneo, T., \& Shafer-Landau, R. (2022). Philosophical methodology: from data to theory. Oxford.

\footnotetext{
109 For first steps on these four problems, see Howard-Snyder and McKaughan (2020), 2021), (forthcoming), and McKaughan and Howard-Snyder (forthcoming).

110 A grant from the John Templeton Foundation supported this publication. The opinions expressed in it are those of the authors and might not reflect the views of the John Templeton Foundation. For helpful feedback on the ideas in this essay, we thank Jeff Cooley, Terence Cuneo, Frances Howard-Snyder, Teresa Morgan, Samuel Lebens, Christian Lee, Michael Pace, Benjamin Schliesser, Neal Tognazzini, David Vanderhooft, Ryan Wasserman, Dennis Whitcomb, and an anonymous reviewer for this journal.
} 
Betz, O. (1990). Firmness in faith: Hebrews 11:1 and Isaiah 28:16. In Jesus: Der Herr der Kirche (pp. 425-446). J. C. B. Mohr.

Biden, J. (2021). Remarks by President Biden on the anniversary of the COVID-19 shutdown. Retrieved Sept 11, 2021, from https://www.whitehouse.gov/briefing-room/speeches-remarks/2021/03/11/ remarks-by-president-biden-on-the-anniversary-of-the-covid-19-shutdown/.

Bishop, J. (2007). Believing by faith: An essay in the epistemology and ethics of religious belief. Clarendon.

Black, C. (2011). Mark. Abingdon Press.

Brooks, D. (2019). A nation of weavers: The social renaissance is happening from the ground up. The New York Times. Retrieved Sept 11, 2021, from https://www.nytimes.com/2019/02/18/opinion/ culture-compassion.html.

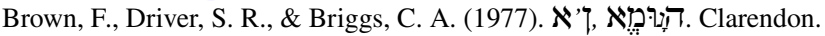

Brown, R. (1982). The message of Hebrews: Christ above all. Intervarsity.

Brueggemann, W. (1986). Genesis. Westminster John Knox.

Buchak, L. (2017). Faith and steadfastness in the face of counter-evidence. International Journal for Philosophy of Religion, 86, 113-133. https://doi.org/10.1007/s11153-016-9609-7.

Cipollone, P. A. (2020). 116th Cong. Rec. 2nd Session 166 (22), (pp. S785). Retrieved Sept 11, 2021, from https://www.congress.gov/116/crec/2020/02/03/CREC-2020-02-03-pt1-PgS773-2.pdf.

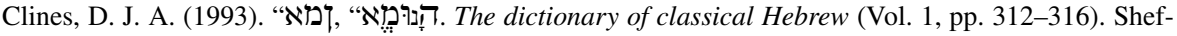
field Academic.

Cocker, J. (1997). Have a little faith in me. https://www.youtube.com/watch?v=n1232F5ZWMo.

Cox, D., La Caze, M., \& Levine M. (2021). Integrity. In E. N. Zalta (Ed.), The stanford encyclopedia of philosophy. Retrieved Sept 11, 2021, from https://plato.stanford.edu/archives/fall2021/entries/integ rity/.

Daily Mail. (2021). Solskjaer insisted he still has faith in his Manchester United squad [Video]. Retrieved Sept 11, 2021, from https://www.dailymail.co.uk/video/football/video-2256846/Video-Solskjaerinsisted-faith-Manchester-United-squad.html.

Duckworth, A. L., Peterson, C., Matthews, M. D., \& Kelly, D. R. (2007). Grit: perseverance and passion for long-term goals. Journal of Personality and Social Psychology, 92, 1087-1101. https://doi.org/ 10.1037/0022-3514.92.6.1087.

Dutta, A. (2021). Manchester united told to keep faith in struggling star. Retrieved Sept 11, 2021, from https://reddevilarmada.com/2021/03/06/manchester-united-told-keep-faith/.

Erickson, B. (2015). People get ready. The national registry. Retrieved Sept 11, 2021, from https://www. loc.gov/static/programs/national-recording-preservation-board/documents/PeopleGetReady.pdf.

Exline, J. J., Pargament, K. I., Grubbs, J. B., \& Yali, A. M. (2014). The religious and spiritual struggles scale: Development and initial validation. Psychology of Religion and Spirituality, 6, 208-222. https://doi.org/10.1037/a0036465.

Fowler, J. (1981). Stages of faith: the psychology of human development and the quest for meaning. Harper-Collins.

Grässer, E. (1965). Der Glaube im Hebräerbrief. Elwert Verlag.

Hartvigsen, K. M. (2012). Prepare the way of the Lord: Towards a cognitive poetic analysis of audience involvement with characters and events in the Markan world. DeGruyter.

Healey, J. P. (1992). Faith: Old Testament. In D. N. Freedman (Ed.), The anchor Yale Bible dictionary. (Vol. 2). Doubleday.

Hahn, S. W. (2009). Kinship by covenant: A canonical approach to the fulfillment of God's saving promises. Yale.

Hehir, J. (director). (2020). The last dance. ESPN Films.

Hiatt, J. (2019). The story behind the song, Top 2000. Retrieved Sept 11, 2021, from https://www.youtu be.com/watch?v=VrDSEk-fSvo.

Hook, J. N., Van Tongeren, D. R., Davis, D. E., Hill, P. C., Hall, M. E. L., McKaughan, D. J., \& Howard-Snyder, D. (2021). Trust in God: An evaluative review of the literature and research proposal. Mental Health, Religion \& Culture, 24, 745-763. https://doi.org/10.1080/13674676.2021.1939291.

Howard-Snyder, D. (2013). Propositional faith: what it is and what it is not. American Philosophical Quarterly, 50, 357-372.

Howard-Snyder, D. (2017a). Markan faith. International Journal for Philosophy of Religion, 81, 31-60. https://doi.org/10.1007/s11153-016-9601-2.

Howard-Snyder, D. (2017b). The skeptical Christian. Oxford Studies in Philosophy of Religion, 8, 142-167. https://doi.org/10.1093/oso/9780198806967.003.0007. 
Howard-Snyder, D. (2019). Can fictionalists have faith? It all depends. Religious Studies, 55, 447468. https://doi.org/10.1017/S0034412518000161.

Howard-Snyder, D., \& McKaughan, D. J. (2020). Faith and humility: Conflict or concord? In M. Alfano, M. Lynch \& A. Tanesini (Eds.), Handbook of the philosophy of humility. Routledge.

Howard-Snyder, D., \& McKaughan, D. J. (2021). The fellowship of the ninth hour: Christian reflections on the nature and value of faith. In J. M. Arcadi \& J. T. Turner Jr. (Eds.), The T\&T clark handbook of analytic theology. Bloomsbury.

Howard-Snyder, D., \& McKaughan, D. J. (Forthcoming). The problem of faith and reason. In J. Fuqua \& J. Greco (Eds.), The Cambridge companion to religious epistemology.

Howard-Snyder, D., \& McKaughan, D. J. (Unpublished). Relying on someone to do something.

Hudson, H. (2021). Fallenness and flourishing.

Hunter-Gault, C. (2020). Reasons for hope amid American's racial unrest. PBS: Race matters, minute 42. Retrieved Sept 11, 2021, from https://www.pbs.org/newshour/show/reasons-for-hope-amidamericas-racial-unrest.

Jackson, E. (2021). Belief, faith, and hope: On the rationality of long-term commitment. Mind, 30, 35-57. https://doi.org/10.1093/mind/fzaa023.

Jeffries, H. (2020). Walk by faith: DJ Trump impeachment closing argument. Retrieved Sept 11, 2021, from https://www.c-span.org/video/?c4851824/user-clip-hakeem-jeffries-walk-faith-impea chment.

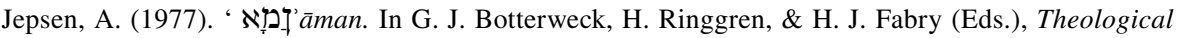
dictionary of the Old Testament (Revised Edition, Vol. 1, pp. 292-323). Eerdmans. Translated by D. E. Green \& J. T. Willis.

Kern, M. L., Benson, L., Steinberg, E. A., \& Steinberg, L. (2016). The EPOCH measure of adolescent well-being. Psychological Assessment, 28, 586-597. https://doi.org/10.1037/pas0000201 10.1037/ pas0000201.supp (Supplemental).

Kinukawa, H. (1994). Women and Jesus in Mark: a Japanese feminist perspective. Orbis.

Kornweibel, T. (2010). African-American railroad experience. Retrieved Sept 11, 2021, from https:// www.kpbs.org/news/2010/mar/23/african-american-railroad-experience/.

Kvanvig, J. (2018). Faith and humility.

Lebens, S. (2017). The life of faith as a work of art: a rabbinic theology of faith. Journal for Philosophy of Religion, 81, 61-81. https://doi.org/10.1007/s11153-016-9600-3.

Lebens, S. (2020). The principles of Judaism.

Lebens, S. (2021). Will I get a job? Contextualism, belief, and faith. Synthese. https://doi.org/10.1007/ s11229-021-03045-3.

Lührmann, D. (1992). Faith: New testament. In D. N. Freedman (Ed.), The anchor Yale Bible dictionary (Vol. 2, pp. 755-756). Doubleday. Translated by F. W. Hughes.

Maddi, S. R., Matthews, M. D., Kelly, D. R., Villarreal, B., \& White, M. (2012). The role of hardiness and grit in predicting performance and retention of USMA cadets. Military Psychology, 24, 19-28. https://doi.org/10.1080/08995605.2012.639672.

Malcolm, F., \& Scott, M. (2021). True grit and the positivity of faith. European Journal of Analytic Philosophy, 17, 5-32. https://doi.org/10.31820/ejap.17.1.1.

Mandela, N. (1994). The long walk to freedom. Little, Brown \& Company.

Marcus, J. (2000). Mark 1-8. Yale.

Marshall, C. (1989). Faith as a theme in Mark's narrative.

Matheson, J. (2018). Gritty faith. American Catholic Philosophical Quarterly, 92, 499-513. https:// doi.org/10.5840/acpq201858152.

McConnell, M. (2020). 116th Cong. Rec. 2nd Session (Vol. 166, No. 24, pp. S91). Retrieved Sept 11, 2021, from https://www.congress.gov/116/crec/2020/02/05/CREC-2020-02-05-pt1-PgS873.pdf.

McKaughan, D. J. (2013). Authentic faith and acknowledged risk: dissolving the problem of faith and reason. Religious Studies, 49, 101-124.

McKaughan, D. J. (2016). Action-centered faith, doubt, and rationality. Journal of Philosophical Research, 41, 71-90.

McKaughan, D. J. (2017). On the value of faith and faithfulness. International Journal for Philosophy of Religion, 81, 7-29. https://doi.org/10.1007/s11153-016-9606-x.

McKaughan, D. J. (2018). Faith through the dark of night: What perseverance amidst doubt can teach us about the nature and value of religious faith. Faith and Philosophy, 35, 195-218. https://doi. org/10.5840/faithphil2018327101. 
McKaughan, D. J., \& Howard-Snyder, D. (2021). Theorizing about faith and faithfulness with Jonathan Kvanvig. Religious Studies. https://doi.org/10.1017/S0034412521000202.

McKaughan, D. J., \& Howard-Snyder, D. (Forthcoming a). Faith and faithfulness. Faith and Philosophy.

McKaughan, D. J., \& Howard-Snyder, D. (Forthcoming). Perseverance in the religious life. In Nathan King (Ed.), Endurance. Oxford.

McKaughan, D. J., \& Howard-Snyder, D. (Unpublished). How does trust relate to faith?

Miller, S. (2004). Women in Mark's Gospel. T\&T Clark.

Moberly, R. W. L. (1997). דן ('āman). In W. A. VanGemeren (Ed.), New international dictionary of Old Testament theology and exegesis (Vol. 1, pp. 427-433). Zondervan.

Morgan, T. (2015). Roman faith and Christian faith: Pistis and fides in the early Roman empire. Oxford.

Neuhaus, R. J. (2000). Death on a Friday afternoon: Meditations on the last words of Jesus from the cross. Basic Books.

Ögtem-Young, Ö. (2018). Faith resilience: Everyday experiences. Societies, 8, 10. https://doi.org/10. $3390 /$ soc8010010.

Pace, M., \& McKaughan, D. J. (2020). Judaeo-Christian faith as trust and loyalty. Religious Studies. https://doi.org/10.1017/S0034412520000153.

Pargament, K. I., \& Exline, J. J. (2020). Religious and spiritual struggle: Research is shedding new light on an overlooked but important human experience. Research in Action. American Psychological Association. Retrieved Sept 11, 2021, from https://www.apa.org/research/action/relig ious-spiritual-struggles.

Peck, M. S. (1987). The different drum. Simon-Schuster.

Perry, E. (1953). The meaning of 'emuna in the Old Testament. Journal of Bible and Religion, 21, 252-256.

Peterson, C., \& Seligman, M. (2004). Character strengths and virtues: A handbook and classification. Oxford.

Pfeiffer, E. (1959). Glaube im Alten testament. Zeitschrift Für Die Alttestamentliche Wissenschaft, 71, 151-164. https://doi.org/10.1515/zatw.1959.71.1-4.151.

Pojman, L. (1986). Faith without belief. Faith and Philosophy, 3, 157-176. https://doi.org/10.5840/ faithphil19863213.

Preston-Roedder, R. (2013). Faith in humanity. Philosophy and Phenomenological Research, 87, 664687. https://doi.org/10.1111/phpr.12024.

Preston-Roedder, R. (2018). Three varieties of faith. Philosophical Topics, 46, 173-199. https://doi. org/10.5840/philtopics201846110.

Rath, B. (2017). Christ's faith, doubt, and the cry of dereliction. International Journal for Philosophy of Religion, 81, 161-169. https://doi.org/10.1007/s11153-016-9608-8.

Rhoads, D. (2004). Reading mark, engaging the Gospel. Fortress.

Romney, M. (2020). 116th Cong. Rec. 2nd Session (Vol. 166, No. 24, pp. S897). Retrieved Sept 11, 2021, from https://www.congress.gov/116/crec/2020/02/05/CREC-2020-02-05-pt1-PgS873.pdf.

Ryken, L. (2016). Jesus the hero: A guided literary study of the gospels. Lexham.

Schellenberg, J. L. (2005). Prolegomena to a philosophy of religion. Cornell.

Seel, N. M. (Ed.). (2012). Fowler faith stages. In Encyclopedia of the sciences of Learning. Springer. https://doi.org/10.1007/978-1-4419-1428-6_2183.

Silver, M. (2015). Seattle Seahawks not pressing the panic button despite 0-2 start. Retrieved Sept 11, 2021, from https:/www.nfl.com/news/seattle-seahawks-not-pressing-the-panic-button-despi te-0-2-star-0ap3000000535727.

Sisto, A., Vicinanza, F., Campanozzi, L.L., Ricci, G., Tartaglini, D., \& Tambone, V. (2019). Towards a transversal definition of psychological resilience: A literature review. Medicina, 55, 745. https:// doi.org/10.3390/medicina55110745.

Smiley, M. (2017). Collective responsibility. In E. N. Zalta (Ed.), The Stanford encyclopedia of philosophy. Retrieved Sept 11, 2021, from https://plato.stanford.edu/archives/sum2017/entries/ collective-responsibility/.

Sovran, T. (2014). Relational semantics and the anatomy of abstraction. Routledge.

Stump, E. (2006). Love, by all accounts. In Proceedings and addresses of the American philosophical association, 80, 25-43. http://www.jstor.org/stable/27645191.

Stump, E. (2012). Wandering in darkness: Narrative and the problem of suffering. Oxford. 
Swanson, D. (2014). Faith, III. Judaism. In C. M. Furey, J. M. LeMon, B. Matz, T. C. Römer, J. Schröter, B. D. Walfish \& E. Ziolkowski (Eds.), Encyclopedia of the Bible and its reception (Vol. 8, EssenesFideism, pp. 701-702). De Gruyter.

Tuggy, D. (2017). Jesus as an exemplar of faith in the New Testament. International Journal for Philosophy of Religion, 81, 171-191. https://doi.org/10.1007/s11153-016-9604-z.

Van Tongeren, D. R., Aten, J. D., McElroy, S., Davis, D. E., Shannonhouse, L., Davis, E. B., \& Hook, J. N. (2019). Development and validation of a measure of spiritual fortitude. Psychological Trauma: Theory, Research, Practice, and Policy, 11, 588-596. https://doi.org/10.1037/tra00 00449.

Whitcomb, D., Battaly, H., Baehr, J., \& Howard-Snyder, D. (2017). Intellectual humility: Owning our limitations. Philosophy and Phenomenological Research, 94, 509-539. https://doi.org/10.1111/ phpr. 12228.

Williams, J. F. (1994). Other followers of Jesus: Minor characters as major figures in Mark's Gospel. Sheffield Academic.

Wolterstorff, N. (1990). The assurance of faith. Faith and Philosophy, 7, 396-417. https://doi.org/10. 5840/faithphil19907438.

Zhao, C. (2021). Chloe Zhao accepts best director academy award for Nomadland [Video]. GMA. Retrieved Sept 11, 2021, from https://www.youtube.com/watch?v=OZUt1LMH-98. 